\title{
Soil microbiota manipulation and its role in suppressing soil-borne plant pathogens in organic farming systems under the light of microbiome-assisted strategies
}

\author{
Ugo De Corato*
}

\begin{abstract}
Soil microbiota plays a key role in suppressing soil-borne plant pathogens improving the natural soil suppressiveness. Microbiome disturbance triggers specific perturbation to change and shape the soil microbial communities' network for increasing suppression against phytopathogens and related diseases. Very important goals have been reached in manipulation of soil microbiota through agronomical practices based on soil pre-fumigation, organic amendment, crop rotation and intercropping. Nevertheless, to limit inconsistencies, drawbacks and failures related to soil microbiota disturbance, a detailed understanding of the microbiome shifts during its manipulation is needed under the light of the microbiome-assisted strategies. Next-generation sequencing often offers a better overview of the soil microbial communities during microbiomes manipulation, but sometime it does not provide information related to the highest taxonomic resolution of the soil microbial communities. This review work reports and discusses the most reliable findings in relation to a comprehensive understanding of soil microbiota and how its manipulation can improve suppression against soil-borne diseases in organic farming systems. Role and functionality of the soil microbiota in suppressing soil-borne pathogens affecting crops have been basically described in the first section of the paper. Characterization of the soil microbiomes network by high-throughput sequencing has been introduced in the second section. Some relevant findings by which soil microbiota manipulation can address the design of novel sustainable cropping systems to sustain crops' health without use (or reduced use) of synthetic fungicides and fumigants have been extensively presented and discussed in the third and fourth sections, respectively, under the light of the new microbiome-assisted strategies. Critical comparisons on the next-generation sequencing have been provided in the fifth section. Concluding remarks have been drawn in the last section.
\end{abstract}

Keywords: Agronomical practice, Amplicon sequencing, Biocontrol agent, Horticulture, Illumina, Soil microbiome disturbance

\section{Background}

Plant diseases caused by soil-borne plant pathogens (filamentous fungi, oomycetes and bacteria) can be effectively suppressed by biotic and abiotic factors of the soil despite

\footnotetext{
*Correspondence: ugo.decorato@enea.it

Division of Bioenergy, Biorefinery and Green Chemistry (DTE-BBC-BIC), Territorial Office of Bari, Italian National Agency for New Technologies, Energy and Sustainable Economic Development (ENEA), Via Giulio Petroni 15/F, 70124 Bari, Italy
}

the presence of virulent pathogens and susceptible hosts [13]. Suppressiveness is a natural characteristic of soil that is accepted worldwide as a management strategy to create sustainable food production ensuring high agricultural productivity levels and low environmental footprints in intensive cropping systems under high pressure of pathogens [113]. Microbiota plays a key role in soil health-regulating dynamics of soil organic matter (SOM) and plant nutrient availability in agroecosystems [115, 
171]. Microbiota represents one of the most important factors that address the success or failure of a defense strategy based, for example, on addition of different levels of municipal waste compost under greenhouse condition for controlling soil-borne pathogens [162].

Combining agronomical practices based on compost and wood to vegetable grown under plastic tunnel, the soil resilience to soil-borne diseases can be consistently reduced over time [25]. However, for turning from a conducive soil into a suppressive ones, robust strategies that by-pass the natural resistance of the soil microbial communities manipulating core microbiomes are needed [82, 203, 208]. Soil microbiota manipulation by organic amendment has been applied since 1980s to reduce either pathogen inoculum or its virulence in conducive soil, although effectiveness of these approaches depends on the pathogen/host system [196]. Very important goals have been reached stimulating the specific disturbance of soil microbiota through agronomical practices focused to change and shape the microbial communities' network for increasing the natural suppressiveness of soil [208, 232]. Supplementation of beneficial exogenous microbiota provided by selected biological control agents (BCAs), organic amendments (OAs) and composts seemed to be promising strategies since 2000s for increasing suppression of conducive soils [40, 56, 94, 181, 210]. OAs from agro-industrial wastes restore soil fertility and enhance the suppressiveness of depleted soils. Efficiency of OAs in suppressing soil-borne plant diseases is generally lower in highly infested soils or in co-infested soils by different pathogens. For instance, robust strategies in fusaria and Verticillium wilts' management were needed if pathogen inoculum is excessive in the soil [114]. Organic amendment was employed as a part of a more complex strategical picture in controlling more soil-borne pathogens basing on their capability to induce disease suppression [15, 93, 127, 128, 156]. Authors documented that combining OAs with BCAs, more beneficial effects in suppressing soil-borne pathogens were obtained [184]. Organic amendment offers promising results in controlling soil-borne diseases also in combination with soil pre-fumigation, where a severe initial destroying of the soil wild microbiota followed by replacement with new microbiomes were both stimulated [194]. Combining soil pre-fumigation with application of bio-organic fertilizer induced pathogen inoculum reduction and disease suppression [193]. Nevertheless, if from one hand OAs can stimulate soil suppressiveness, on the other hand it can increase disease incidence and/ or disease severity inducing soil to become conducive [24]. Despite some contradictory data, the integrated agricultural strategies based on the combined use of OAs and BCAs tailored composts and microbial consortia from disease-suppressive composts, and novel bioorganic fertilizers with organic additives (as silicon and chitin) were accepted worldwide for controlling multiple soil-borne pathogens [50, 56, 57, 97, 138, 238]. These practices induce rhizosphere health by beneficial alterations of its microbiota. To limit inconsistencies, drawbacks and failures related to soil microbiota disturbance, a detailed understanding of the microbiomes is needed under the light of microbiome-assisted strategies [152]. From one hand, authors have excellently reviewed how soil microbiota and tree crops health can be assessed in forest agroecosystems by next-generation sequencing (NGS), where high-throughput sequencing (HTS) offers a wide overview of the soil microbial communities under disturbance of their microbiomes more than traditional microbiological and biochemical-based methods [159]. On the other hand, very fewer papers regarding the critical revision of the impacts of agronomical practices on agroecosystem health for increasing disease suppression in horticultural farming systems have been found in the literature.

This review work reports and discusses the most reliable findings in relation to a comprehensive understanding of soil microbiota and how its manipulation can improve suppression against soil-borne diseases in organic farming systems. Role and functionality of the soil microbiota in suppressing soil-borne pathogens affecting crops were basically described in the first section of the paper. Characterization of the soil microbiomes network by highthroughput sequencing was introduced in the second section. Some relevant findings by which soil microbiota manipulation can address the design of novel sustainable cropping systems to sustain crops' health without use (or reduced use) of synthetic fungicides and fumigants were extensively presented and discussed under the light of the new microbiome-assisted strategies in the third and fourth sections, respectively. A critical comparison and some advancements on next-generation sequencing technology for agricultural purposes were provided and discussed in the fifth section. Concluding remarks were drawn in the last section.

\section{Role and functionality of the soil microbiota in suppressing soil-borne plant pathogens}

Soil microbiota in suppressing soil-borne pathogens was studied since 1970s. Researches showed that suppressive soils can control pathogens, thus stimulating further studies in search of different types of diseasesuppressive soils. The most recent works documented that microbiota of certain soils can create adverse environmental conditions for development of plant pathogens, so generating an additional suppressiveness level to those naturally present in the soils. Suppression is mainly 
driven by the soil microbial community and SOM, and also its capacity to improve plant nutrition and vigor. Natural capacity to suppress pathogens has been studied in many disease-suppressive soils against the oomycetes and fungi Pythium ultimum, Pythium irregulare, Pythium aphanidermatum, Phytophthora nicotianae, Phytophthora capsici, Phytophthora cinnamomi, Rhizoctonia solani and Fusarium oxysporum [105]. The understanding of disease suppressive mechanisms is a crucial step to enhance the suppressive effect by manipulation of the soil microbiota. More specifically, the suppressive properties can be explained through combined antimicrobial actions exerted by molecules and microbes or mechanisms of antagonism among microbes and pathogens. The biological factors based on disease suppression generally include a combination of different actions. The mechanisms underlying the suppressive effect are primarily associated with the biological activity of soil microbiota which interacts with the SOM as well as the host plant. The most important factors are represented by the increased microbial activity [155] and fungistasis [27], enhanced soil structure [32], release of mineral nutrients during SOM decomposition [18], activation of competition for space and nutrients [170], elicitation of microbiostasis and hyperparasitism [92], release of diffusible antibiotic-like compounds [224] and activation of systemic disease-resistance in the host plant [33]. A "general suppression effect" is attributed to microbial biomass affecting more than one pathogen simultaneously where diversified mechanisms are activated offering a basal protection against a broad range of pathogens. Competition and production of antibiotics are involved in the general suppression mechanisms that do not easily transferable from one soil to another. Unlikely, a "specific suppression effect" is most easily transferable among soils because it is attributed to few microbial taxonomic groups active against one or few pathogens. Predation, parasitism and activation of disease resistance are involved in the specific suppression mechanisms. These two broad soil classes are not mutually exclusive in relation to their suppression models but often co-exist [105].

Biocontrol-based microbiota includes bacteria (Bacillus, Paenibacillus and Pseudomonas), actinomycetes (Streptomyces) and filamentous fungi (Trichoderma, Fusarium, Gliocladium, Aspergillus and Penicillium) that can trigger all mechanisms associated to disease suppression. In particular, microbiota of disease-suppressive compost contains Plant Growth-Promoting Rhizobacteria (PGPR) and non-pathogenic species of Fusarium and Pythium (i.e., F. oxysporum and Pythium oligandrum) which can improve plant growth and vegetative vigor, so rending host more resistant or tolerant to disease [39, 101]. Certain soils can even stimulate plant growth and vigor and/or induce nutrient availability and uptake for promoting crop productivity by a varied microbiota of fluorescent pseudomonads, species of Bacillus, Paenibacillus, actinomycetes and arbuscular mycorrhizal fungi (AMF) related to disease suppression. Fluorescent pseudomonads directly not only suppress pathogen in rhizosphere [29], but can also improve nutrient uptake [64] and produce plant growth-promoting substances [185]. Paenibacillus brasilensis can fix atmospheric nitrogen [216] and produce auxin [53] and cytokinin [206]. Species of Bacillus, actinomycetes and AMF can increase the soluble phosphorus uptake [58]. Species of AMF and P. oligandrum can induce anatomical and morphological change in root system [177], alter rhizosphere profile [161] and balance the root loss with new biomass [48]. Evidence suggests that soil capability to suppress plant pathogens primarily depends on capacity of soil to support microbial growth and bioactivity. The complex interactions among beneficial microbes, pathogens, SOM and physicochemical properties (as $\mathrm{pH}$, electrical conductivity, macro-micronutrients content) are the focal points of the success (or failure) of disease-suppressive compost-amended soils [84].

Suppression of Fusarium wilts is triggered by restrict groups of microorganisms acting synergistically [2, $23,124,145]$. Authors have highlighted that competition for nutrients is one of the primary mechanisms by which disease-suppressive soils are capable for controlling Fusarium diseases [3]. Soil suppressiveness to Fusarium wilt of tomato has been ascribed to carbon and iron competition between the pathogenic $F$. oxysporum isolates in rhizosphere with the nonpathogenic endophytic strain Fo47 of F. oxysporum and the wild populations of fluorescent pseudomonads, respectively [83, 130]. Production of siderophores is identified as the primary mechanism by which fluorescent pseudomonads suppress Fusarium wilt of tomato. Siderophores can chelate ferric ion $\left(\mathrm{Fe}^{3+}\right)$ from the soil into living cells of fluorescent pseudomonads such rendering iron unavailable for the pathogen. Siderophores play a crucial role in nutrient competition for the infection sites among pathogens and beneficial microorganisms [119]. In addition, other overall mechanisms include the production of secondary metabolites resulted to be toxic for pathogen. Particularly, the genera Bacillus and Paenibacillus are both highlighted as two among the most representatives "top-BCAs" in suppressing Fusarium wilt of tomato, regulating the microbial community of rhizosphere through production of toxic metabolites for increasing plant protection and growth stimulation (Aydi Ben [11]. Paenibacillus polymyxa NSY50 is reported as an effective top-BCA for controlling Fusarium wilt of cucumber [195]. A 
direct inhibition on conidial germination and mycelium growth of plant pathogens induced by Bacillus, Pseudomonas, Streptomyces, Trichoderma and Penicillium has been documented against phytopathogenic fungi using compost water extract [72, 153, 196]. Actinobacteria resulted to be consistent in suppressive compost-amended soils where the increased population of beneficial microorganisms should be more competitive for the ecological niches, so leading to reduction in pathogen infection. The genus Streptomyces has been reported as the strongest producer of antibiotics and/or others toxic metabolites (over two-thirds of the natural antibiotics are produced by Streptomyces sp.) for inducing disease suppression and promoting plant growth in enhancing the beneficial bioactivity of plantassociated bacteria by direct and indirect mechanisms $[117,173]$. The genus Streptomyces has been identified as an effective top-BCA against Fusarium wilt of cucumber and tomato being associated with the suppressive properties against bacterial and fungal wilts [157]. For instance, Streptomyces violaceus-niger XL-2 produces tubercidin, phosphalactomycin, candicidin and other antifungal compounds [100, 192]. Streptomyces albospinus CT205 can act alone [219] or synergistically with Bacillus amyloliquefaciens SN16-1 [217] to control Fusarium wilt of cucumber and tomato, respectively. Authors have studied the suppressive effect against tobacco bacterial wilts treating the soil with $B$. amyloliquefaciens ZM9 to enrich tobacco rhizosphere with new phyla associated to potential BCAs [226]. Suppression of Fusarium oxysporum f. sp. melonis in wilt-suppressive soils and composted green wastesamended soils has been associated to populations of Aspergillus, Streptomyces and fluorescent Pseudomonas $[43,200]$. Sewage sludge compost suppresses F. oxysporum f. sp. melonis wilt on tomato if combined with selected Trichoderma asperellum isolates [49]. Others authors instead concluded that species of Penicillium can act as top-BCAs against Fusarium oxysporum f. sp. lycopersici of tomato [99].

Likely to suppression of fusaria-related wilts, suppression of $V$. dahliae of cotton after soil supplementation with olive mill compost has been related to populations of Actinomycetes (mainly Streptomyces) [10]. Influence of different application rates and delivery methods on crop protection triggering various host defense mechanisms and rhizosphere populations of BCAs against $V$. dahliae wilts was studied by [5]. Suppression of Verticillium dahliae wilt of olive planting stocks by root-associated fluorescent pseudomonads was investigated by MercadoBlanco et al. [160]. Suppression of $V$. dahliae of eggplant by supplementation with composted tomato waste in conducive soil has been attributed to biological action of
Bacillus and fluorescent pseudomonads [112] or to systemic resistance induced by species of Trichoderma [95].

Suppression of Rhizoctonia diseases also resulted to be induced by restrict groups of microorganisms acting synergistically [212]. Suppression of Rhizoctonia dampingoff, collar rot and root rot by soil amendment with green composts resulted to be most variable and unpredictable in many horticultural soil-less systems [45, 120, 122, 175]. The primary mechanism of action ascribed to Trichoderma harzianum in suppressing Rhizoctonia diseases is primarily related to cell wall degrading of the pathogen due to action of lytic enzymes such as $\beta$-1,3-glucanase, chitobiase, hydrolases and chitinase [59]. As Trichoderma recognizes the host, it attaches itself the host and afterward grows along the host hyphae or coils around them by secreting lytic enzymes [212]. It has been documented that chitinolytic enzymes from $T$. harzianum inhibit spore germination and germ tube elongation in plant pathogens $[46,88]$. Capability of degrading cell walls or inactivating overwinter resistant propagules of $R$. solani has been attributed to action of Trichoderma aureoviride DY-59 and Rhizopus microsporus VS-9 [169]. As well, harzianic acid showed antibiotic activity against $R$. solan $i$ and P. irregulare [214], while strains of Trichoderma can produce non-volatile antibiotics that inhibit and predispose the host hyphae to infection before contact being occurred [212]. Authors have studied a significant suppressive potential of the purified active compounds from cultural filtrate of Bacillus subtilis subsp. subtilis C9 for using as BCA against $R$. solani on Zoysia grass, as well as plant growth promoter with the ability to trigger induced systemic resistance on grass [102].

Suppression of the oomycetes Pythium spp. and Phytophthora spp. causing damping-off and root rot is instead driven by nonspecific mechanisms determining a biological buffering power in soil rather than elicit specific suppressive responses [116]. Basal protection can be stimulated by soil supplementation with compost for enhancing the microbial activity [16]. Authors have documented that microbial biomass is able to suppress $P$. ultimum, $P$. aphanidermatum, and $P$. irregulare in cucumber, tomato, and melon, respectively; $P$. nicotianae in tomato; and $P$. cinnamomi in azalea [55] eliciting overall mechanisms related to SOM accumulation and optimization of its humification degree [44, 87, 147, 188]. Microbial consortia engage in a competition with the pathogens for space and nutrients, or resulting in antagonism among biocontrol-based microorganisms and pathogens. Moreover, authors highlighted an increased soil biological activity in disease suppression by an enhanced biological activities of the soil respiration rate, fluorescein diacetate hydrolysis, as well as several enzymatic activities (overall $\beta$-glucosidase, dehydrogenase, arylsulphatase and 
alkaline phosphatise). In the case of soil supplemented with on-farm composted tomato residues, all biological activities resulted to be significantly increased and directly correlated to active microbial biomass for controlling Fusarium wilt in a tomato cropping system [174].

It is important to underline that plants grown in compost-amended soils are colonized by large variety of microorganisms from which several strains capable of inducing resistance in planta have been described [60, $136,151,222]$. Once resistance is induced, abundance of the strains declines without affecting resistance [183], but such strains must be present above a certain threshold abundance for inducing valuable disease-resistance effects.

\section{Characterizing the soil microbiomes by NGS technology}

Microbial genome sequencing has become main tool in the applied soil microbiology and ecology due to the increasing affordability and improvements in the speed of sequencing and quality of the data. This is a consequence of the advancement in NGS technologies that encompass both massively parallel and single-molecule sequencing by providing short and long sequencing reads, respectively. Short-read sequencing is highly accurate and produces read lengths of 100-300 bp which are afterward assembled into draft genomes since complete genomes cannot be generated from the short-reads obtained in a single sequence run, due to difficulties in assembling repetitive regions and large genomic rearrangements such as insertions, deletions and inversions. For many applications, including comparative genomics and phylogeny studies for soil microbial communities, complete genomes are required for determining complex genomic regions where longer reads are needed. Long-read sequencing produces read lengths from 10 to $50 \mathrm{~Kb}$, but this is at the cost of higher error rates [139]. Currently, microbial DNA sequencing performed on Illumina, Ion Torrent, PacBio and Nanopore sequencing are well described $[63,191,198]$. Where technology is used depending on what the sequencing data are to be used for the amplicon throughput sequencing. Maximizing high throughput capabilities will result in low sequencing cost per sample. However, the number of samples sequenced in a single run is a function of the desired output and coverage, and this depends on the application. For example, single nucleotide polymorphism analysis of bacterial genomes can be performed with relatively low coverage meaning more DNA samples processed in a single sequencing run. In contrast, metagenomics analysis aimed at identifying all microbial genes present in a sample needs far greater coverage such as limiting the number of samples that can be processed in a single run and increasing the sequencing cost per sample.

NGS probes the species and functional diversity of the soil microbial communities without culture media through two main approaches: (i) amplicon sequencing (or metabarcoding), which involves the amplification and sequencing of specific marker gene families; and (ii) metagenomics, that includes the random shotgun sequencing of the whole genomic content of the microbial communities. It is important to differentiate among these two approaches that are sometime erroneously combined under the term metagenomics or often confuse among them [77]. Authors recommend of using the term "metabarcoding" when applying ampliconbased techniques and the term "metagenomics" only when untargeted shotgun sequencing is applied. However, both techniques eliminate the requirement for single colony isolation in a growing medium and have been highly successful for identifying and investigating uncultivable microorganisms [34]. In particular, amplicon-based microbial community profiling requires the isolation of DNA directly from the sample that can include a soil, compost, biochar, OAs and microbial consortia. Extracted DNA undergoes targeted PCR amplification of phylogenetic marker genes; commonly the $16 \mathrm{~S}$ rRNA gene for Prokaryotes (Archaea and Bacteria), the $18 \mathrm{~S}$ rRNA gene for Eukaryotes (Protists), and the internal transcribed spacer (ITS) of the ribosomal gene cluster sequences for other Eukaryotes (Yeast, Oomycetes and Fungi). Massive parallel sequencing of amplicons afterward generates an array of profiling information of the complex microbiota associated with the microbiome profiles. The sequencing data are then processed by dedicated bioinformatics pipelines to structure and annotate this raw information into knowledge. One of the most benefits of amplicon sequencing is the ability to follow the succession of microbial populations at various taxonomic levels over time, so allowing the differentiation of closely related microbial taxa using $16 \mathrm{~S}$ rRNA gene sequence data for bacterial characterization [73]. If compared to random shotgun sequencing (metagenomics), metabarcoding provides a more cost-effective overview of the taxonomic composition of a sample. In fact shotgun metagenomics, generating sequencing information from the genetic material in a sample, permits the identification of individual strains and allows the prediction of functions encoded by microbial communities. This approach has allowed the measurement of population diversity levels in situ [14, 213] and the determination of specific genes in a habitat [211]. However, shotgun metagenomics provides an opportunity to survey the diversity and the dynamic abundance of microorganisms within a sample in a less-biased manner 
than metabarcoding being used to improve culture-based enrichment methods [77]. Shotgun metagenomics can provide a valuable and speed view of the presence of genetic markers specifying species, serotype, virulence genes, etc., although these markers usually cannot be assigned to specific bacterial genomes due to the complexity of the metagenomic data [132, 235].

NGS resulted to be a better option for understanding the BCAs population shifts in composts [52, 118, 207]. The 16S rRNA gene has been a mainstay of the sequencebased analysis for decades [52]. Sequence analysis of smaller rRNA-subunit genes in bacteria (16S rRNA) from soil-extracted nucleic acids samples was PCR-amplified for microbiome analyses. Sequence analysis of larger fragments of the internal transcribed spacer 1 (ITS1) region of the ribosomal RNA (ITS rRNA) gene in fungi was amplified for microbiome analyses $[178,189]$. Amplicon HTS have developed multiple integrated platforms of 1st and 2nd generation (Roche 454-pyrosequencing and Illumina/Solexa (or Illumina), respectively) with higher processing speed due to their high production capacity in a single sequencing run. Advancements based on the HTS platforms of 3rd and 4th generation (Ion Torrent/Ion Proton, PacBio and Oxford Nanopore, respectively) can be applied for deeper understanding the soil microbiota. Microbial rRNA gene sequences can be targeted using appropriate databases by comparing with known microorganisms [106]. For instance, taxonomic and phylogenetic affiliation of fungi can be based either on databases provided by the National Centre for Biotechnology Information (NCBI) or on most stable and reliable bioinformatics pipelines for soil fungal sequencebased identification (UNITE). Metagenomics libraries and databases for assessing the microbial community structure and functionality related to disease suppression have been developed $[1,47,62]$ thanks to the implementation of new platforms [36, 37, 69-71, 144, 231]. Sequence Read Archive (SRA) database stores microbiome sequence data from the researchers' network as a new bio-project providing an international identification code number for each one. SRA helps to provide detailed information about the microbiota structure in terms of abundance, richness, diversity, evenness and composition, such allowing to identify potential unknown BCAs and functional genes involved in plant disease suppression during microbiome manipulation $[66,168,180]$. However, there are other ways of analyzing amplicon sequencing data. Important initiatives have been implemented by the Earth Microbiome Project (EMP) (http:// www.earthmicrobiome.org) and the Genomic Standards Consortium (GSC). Both the projects provide a number of standards and guidelines for soil microbiome analyses which are helpful if the data from a single bio-project are compared with those of relevant studies in meta-analysis contexts. EMP and GSC both intend to standardize the pipelines and bioinformatics platforms giving recommendations and guidelines for performing the soil microbiome analyses [131].

\section{Soil microbiota disturbance for increasing soil disease suppression addresses the design of novel organic farming systems under the light of microbiome-assisted strategies}

The four major questions to better understand the abundance, composition and diversity of the soil microbiome communities including biocontrol-based microbiomes are the following: (i) Who are there? (ii) How many are there? (iii) How are they different? and (iv) What are they doing? As a result of the most recent advancements in NGS, our understanding of the soil microbiomes may help to respond, at least partly, the first three questions. Due to their high reliability and sensitivity more than culture-based enrichment methods, amplicon sequencing represents a powerful toolbox to study the microbiome shifts in manipulated soils where a relevant number of new insights have been published over the last decades [165].

Soil microbiota manipulation has implemented a great number of studies related to suppression of plant pathogens adopting suitable agronomical practices for sustainable agroecosystems. Novel organic farming systems based on the reduced use (or without use) of synthetic chemicals (fungicides and fumigants) have been designed under the light of microbiome-assisted strategies [232]. At this regard, a recent work was aimed at determining the soil microbiota change using Illumina MiSeq sequencing. The BCA populations involved in soil disease suppression against Fusarium oxysporum f. sp. cubense of banana were tracked in both suppressive and conducive soils during the pathogen colonization [172]. The hypervariable V4 region of the bacterial 16S rRNA gene was amplified using the primer pair 520F/802R. The fungal ITS 1 region of the ITS gene was amplified using the primer pair ITS1F/ITS2R. The authors have found distinct microbiome patterns among the soils. Alpha- and Beta-diversity parameters for comparing the microbial diversity [141] resulted to be increased (or did not significantly changed) and decreased in the suppressive soil and conducive soil, respectively, so indicating that the microbiomes were notably different between the two soils. The microbiome network resulted more complex in a phylogenetic context showing a higher number of negative correlations between abundance of bacterial taxa and incidence (and severity) of Fusarium wilt in the suppressive soil than in those conducive. The authors identified the bacterial genera Chryseolinea, Terrimonas 
and Ohtaekwangia as "new key taxa" that likely conferred an additional suppressiveness level to soil against Fusarium wilt of banana. The results of this study may help to guide efforts for targeting suitable cultivation systems which may lead to develop new and effective biocontrolbased tools against soil-borne diseases basing on the new potential BCAs.

To reveal new insights from soil microbiota manipulation that can be taken as future case study for increasing soil disease suppression, it is fundamentally important to address this paper toward the most reliable agronomical practices supported by microbiome-assisted strategies that use amplicon sequencing platforms. Particularly, the long-term supplementation of plant residues, alone or in combination with OAs and BCAs (Table 1); the combined treatment of soil pre-fumigation with application of composts, un-decomposed plant residues and biochar; and the microbiota recruitment techniques from compost into top soil (Tables 2 and 3 ) have been reported in literature as suitable tools.

Since application of OAs, BCAs and composts seems to be the most reliable strategies, it is due to recall that different typologies of OAs made of plant residues and green manure [90, 202], organic wastes [51, 209] and biochar $[110,129]$ have been studied as the effective means for recovering the fertility loss in depleted soils and in increasing disease-suppressiveness for conducive soils. The beneficial effects of soil suppressiveness in many host/pathogen systems by supplementation of OAs have been described $[80,96,186]$ and the mechanisms to explain the beneficial effects of OAs on soil suppressiveness and plant health have been in-depth studied [91, 126, 179]. Nonetheless, OAs could have significant drawback effects that limit their applicability in agroecosystems because the suppressive capability can be inconsistent or difficult to predict [204]. On the other hand, compost is defined as "a matured and stabilized organic matter naturally enriched during composting process with hydrophobic carbonaceous molecules and humic substances, such as humic and fulvic acids and umina, which make it a biomass more recalcitrant to further degradation" (ISO/IEC 17025:2005). Compost derives from a biological oxidative process termed as "bio-composting" by which biodegradable organic substances are aerobically transformed into stable and humified substances after curing period. Composts are used in organic farming systems for their positive effects that induce on plant growth and crop protection (ISO/IEC 17025:2005). Biocomposting has been recognized as one of the most costeffective biological treatments of the agricultural biomass being defined as " $a$ natural and sustainable biological process which transforms highly degradable organic biomasses into stabile and mature biomasses due to the action of endogenous microbiota" (ISO/IEC 17025:2005). Bio-oxidative transformation is due to complex interactions between substrate and microbiota in the solid phase where the production of high temperature (ranging from 55 to $78^{\circ} \mathrm{C}$ ) for at least $5-7$ consecutive days during the thermophilic phase represents a crucial step that allows biomass sanitization up to pathogen-free compost. Compost is technically defined as an organic amendment (or bio-fertilizer) that maintains and enhances the fertility and productivity of soils inducing a manipulation of the soil microbial communities $[176,187]$ under intensive farming systems [190]. Studies have demonstrated that compost addition not only provides important macroand micronutrients in soil $[68,75,81]$, but also increases soil organic carbon stock [89], improves soil structure [41] and water-holding capacity [38], enhances crop yield [237] and suppresses soil-borne pathogens [28, 54]. Authors have observed that soil microorganisms were more sensitive to compost addition in a significant manner using different application rates $[8,78]$, while other studies have showed that compost addition may have positive [17, 242], neutral [164] or even negative effects on soil microbial diversity and biological activity [150].

Table 4 shows that Roche 454-pyrosequencing has been used to study the crop yield improvement and soil fertility in an Italian rocket cropping system [26, 42]. Manipulating soil microbiomes by fumigation treatment in combination with application of straw, compost and biochar at different rates, frequencies and application times, these authors have obtained significant microbiota shifts in suppressing soil-borne rocket diseases. Other study has investigated the beneficial effects of the on-farm co-composted cow manure and maize straw at different application rates in a soybean cropping system [234]. Since the soil fungi community determines the agroecosystems' functionality being strongly influenced by the amendment with compost, these authors have studied the soil fungal community profiles of the new microbiome patterns using Illumina MiSeq sequencing in different soybean growing stages (seedling, flowering and harvesting) in relation to yield and quality improvement. Other study has investigated the soil microbial activity related to the bacterial and fungal microbiomes by Illumina in a preconditioned biochar-amended plant growth medium for enhancing the indigenous microbial community [104]. These authors have evaluated the maximum benefit for plant productivity and disease suppression against $P$. aphanidermatum damping-off in a cucumber cropping system. Other authors have focused their interest on the impact of manipulated rhizospheres in an organic farming system by long-term supplementation of plant residues in combination with BCAs [65]. They provided new insights on the beneficial effects regarding the SOM 
Table 1 Combining organic amendments with biocontrol agents for controlling soil-borne plant pathogens

\begin{tabular}{|c|c|c|c|c|}
\hline Organic amendment & Biocontrol agent & $\begin{array}{l}\text { Target pathogen (fungi } \\
\text { and oomycetes) }\end{array}$ & Disease/host plant & References \\
\hline \multicolumn{5}{|l|}{ Fungi } \\
\hline Wheat bran, peat moss & Trichoderma harzianum & Sclerotium cepivorum & White rot/Allium & Avila Miranda et al. [9] \\
\hline Vermicompost, neem cake & T. harzianum & $\begin{array}{l}\text { Fusarium solani f. sp. melon- } \\
\text { geneae }\end{array}$ & Fusarium wilt/Eggplant & Bhadauria et al. [20] \\
\hline Vineyard pruning waste & T. harzianum & $\begin{array}{l}\text { Fusarium oxysporum f. sp. } \\
\text { melonis }\end{array}$ & Fusarium wilt/Melon & Blaya et al. [23] \\
\hline Cow dung & T. harzianum & $\begin{array}{l}\text { F. oxysporum } \\
\text { Sclerotium rolfsii }\end{array}$ & Foot rot/Lentil & Hannan et al. [86] \\
\hline $\begin{array}{l}\text { Green compost from pig } \\
\text { manure, rice straw, alcohol, } \\
\text { vinegar }\end{array}$ & $\begin{array}{l}\text { Trichoderma harzianum } \\
\text { SQR T037 }\end{array}$ & $\begin{array}{l}\text { Fusarium oxysporum f. sp. } \\
\text { cucumerinum }\end{array}$ & Fusarium wilt/Cucumber & Yang et al. [233] \\
\hline Fresh chicken manure & $\begin{array}{l}\text { Trichoderma asperellum } \\
\text { Trichoderma atroviridae }\end{array}$ & Macrophomina phaseolina & Charcoal rot/Strawberry & Domínguez et al. [67] \\
\hline $\begin{array}{l}\text { Farm yard manure and poul- } \\
\text { try manure }\end{array}$ & Trichoderma viridae & $\begin{array}{l}\text { Pythium sp., Rhizoctonia solani, } \\
\text { Phytophthora sp., Fusarium } \\
\text { sp. }\end{array}$ & Damping off/Tomato & Joshi et al. [111] \\
\hline $\begin{array}{l}\text { Green compost from cork, } \\
\text { grape, olive marc, and } \\
\text { spent mushroom }\end{array}$ & T. asperellum & R. solani & Damping-off/Cucumber & Trillas et al. [210] \\
\hline $\begin{array}{l}\text { Composted sawdust, potato } \\
\text { waste, and rice straw }\end{array}$ & $\begin{array}{l}\text { T. harzianum } \\
\text { Penicillium oxalicum Chaeto- } \\
\text { mium globosum }\end{array}$ & F. oxysporum & Fusarium wilt/Legumes & Haggag and Saber [85] \\
\hline \multicolumn{5}{|l|}{ Bacteria } \\
\hline $\begin{array}{l}\text { Compost from pig manure, } \\
\text { canola cake }\end{array}$ & Bacillus subtilis SQR 9 & $\begin{array}{l}\text { F. oxysporum f. sp. cucumeri- } \\
\text { num }\end{array}$ & Fusarium wilt/Cucumber & Cao et al. [35] \\
\hline $\begin{array}{l}\text { Amino acid fertilizer from } \\
\text { rapeseed meal fermenta- } \\
\text { tion, and compost from } \\
\text { pig manure }\end{array}$ & B. subtilis & Verticillium dahliae & Verticillium wilt/Cotton & Lang et al. [123] \\
\hline $\begin{array}{l}\text { Amino acid fertilizer from } \\
\text { rapeseed meal }\end{array}$ & Bacillus pumilus SQR-N43 & R. solani & Damping-off/Cucumber & Huang et al. [98] \\
\hline $\begin{array}{l}\text { Compost from pig manure, } \\
\text { canola cake }\end{array}$ & Bacillus amyloliquefaciens W19 & $\begin{array}{l}\text { Fusarium oxysporum f. sp. } \\
\text { cubense }\end{array}$ & Fusarium wilt/Banana & Wang et al. [221] \\
\hline Pig manure, rice straw & B. amyloliquefaciens & Ralstonia solanacearum & Bacterial wilt/Tomato & Wei et al. [223] \\
\hline $\begin{array}{l}\text { Farm yard manure, compost, } \\
\text { poultry manure, press } \\
\text { mud, vermicompost, and } \\
\text { neem cake }\end{array}$ & Pseudomonas fluorescens & Pythium aphanidermatum & Damping off/Tomato & Jayaraj et al. [107] \\
\hline \multicolumn{5}{|l|}{ Fungi + Bacteria } \\
\hline $\begin{array}{l}\text { Neem cake, farm yard } \\
\text { manure, and micronutrient }\end{array}$ & $\begin{array}{l}\text { T. viridae } \\
\text { P. fluorescens } \\
\text { B. subtilis }\end{array}$ & Lasiodiplodia theobromae & Physic nut collar and root rot & Latha et al. [125] \\
\hline Mustard oil cake & $\begin{array}{l}\text { P. fluorescens } \\
\text { Glomus sinuosum } \\
\text { Gigaspora albida }\end{array}$ & R. solani & Root rot/Bean & Neeraj [167] \\
\hline Olive mill waste & $\begin{array}{l}\text { B. amyloliquefaciens } \\
\text { Burkholderia cepacia }\end{array}$ & V. dahliae & Verticillium wilt/Olive & Vitullo et al. [215] \\
\hline $\begin{array}{l}\text { Compost from pig manure, } \\
\text { canola cake }\end{array}$ & $\begin{array}{l}\text { T. harzianum Paenibacillus } \\
\text { polymyxa }\end{array}$ & $\begin{array}{l}\text { Fusarium oxysporum f. sp. } \\
\text { niveum }\end{array}$ & Fusarium wilt/Watermelon & Wu et al. [227] \\
\hline $\begin{array}{l}\text { Commercial organic fertilizer } \\
\text { made of compost from pig } \\
\text { manure, canola cake }\end{array}$ & $\begin{array}{l}\text { P.polymyxa } \\
\text { B. subtilis } \\
\text { Penicillium spp. } \\
\text { Aspergillus spp. }\end{array}$ & F. oxysporum f. sp. melonis & Fusarium wilt/Melon & Zhao et al. [239] \\
\hline
\end{tabular}


Table 2 Next-generation disease-suppressive composts collection

\begin{tabular}{|c|c|c|c|c|c|c|}
\hline $\begin{array}{l}\text { Compost } \\
\text { item }\end{array}$ & $\begin{array}{l}\text { Compost } \\
\text { code }\end{array}$ & $\begin{array}{l}\text { Feedstock: } \\
\text { Agricultural } \\
\text { waste and agro- } \\
\text { industrial } \\
\text { residues } \\
\text { and co-product }\end{array}$ & $\begin{array}{l}\text { Feedstock: Plant } \\
\text { green-waste, } \\
\text { Plant sludge }\end{array}$ & $\begin{array}{l}\text { Feedstock: } \\
\text { Organic fraction } \\
\text { of municipal } \\
\text { solid waste, cattle } \\
\text { manure and other } \\
\text { bio-wastes }\end{array}$ & Target pathogen (fungi and oomycetes) & $\begin{array}{l}\text { Susceptible } \\
\text { host }\end{array}$ \\
\hline \multirow[t]{4}{*}{$\begin{array}{l}\text { Green com- } \\
\text { posts\#1 }\end{array}$} & Com- $A^{a}$ & $\begin{array}{l}\text { Defatted olive } \\
\text { marc }\end{array}$ & Fennel waste & - & \multirow{4}{*}{$\begin{array}{l}\text { Verticillium dahliae Rhizoctonia solani Phy- } \\
\text { tophthora nicotianae } \\
\text { Phythophthora cinnamomi } \\
\text { Pythium ultimum } \\
\text { Pythium irregulare }\end{array}$} & \multirow{4}{*}{$\begin{array}{l}\text { Eggplant } \\
\text { Bean, Pea } \\
\text { Tomato } \\
\text { Azalea } \\
\text { Cucumber } \\
\text { Melon }\end{array}$} \\
\hline & Com- $B^{a}$ & $\begin{array}{l}\text { Un-defatted olive } \\
\text { marc }\end{array}$ & Artichoke waste & - & & \\
\hline & Com- $C^{a}$ & Coffee ground & $\begin{array}{l}\text { Celery waste + car- } \\
\text { rot waste }\end{array}$ & - & & \\
\hline & Com-Da & Tea bag & $\begin{array}{l}\text { Tomato } \\
\text { waste + lettuce } \\
\text { waste }\end{array}$ & - & & \\
\hline \multirow[t]{3}{*}{$\begin{array}{l}\text { Green com- } \\
\text { posts\#2 }\end{array}$} & Com- $E^{a}$ & Wood chip & $\begin{array}{l}\text { Tomato } \\
\text { waste+escarole } \\
\text { waste }\end{array}$ & - & \multirow{3}{*}{$\begin{array}{l}\text { V. dahliae } \\
\text { R. solani } \\
\text { P. nicotianae } \\
\text { P. ultimum }\end{array}$} & \multirow{3}{*}{$\begin{array}{l}\text { Eggplant } \\
\text { Bean } \\
\text { Tomato } \\
\text { Cucumber }\end{array}$} \\
\hline & Com- $\mathrm{F}^{\mathrm{a}}$ & Aspen chip & $\begin{array}{l}\text { Artichoke } \\
\text { waste + fennel } \\
\text { waste }\end{array}$ & - & & \\
\hline & Com- $\mathrm{G}^{\mathrm{a}}$ & $\begin{array}{l}\text { Vineyard pruning } \\
\text { wastes + vin- } \\
\text { ery resi- } \\
\text { dues + wheat } \\
\text { straw }\end{array}$ & $\begin{array}{l}\text { Potato } \\
\text { waste + pepper } \\
\text { waste }\end{array}$ & - & & \\
\hline \multirow[t]{4}{*}{$\begin{array}{l}\text { Green com- } \\
\text { posts\#3 }\end{array}$} & $\mathrm{Com}-\mathrm{C} 1^{\mathrm{b}}$ & $\begin{array}{l}\text { Vineyard pruning } \\
\text { wastes }\end{array}$ & $\begin{array}{l}\text { Pepper } \\
\text { sludge + pepper } \\
\text { waste }\end{array}$ & - & P. nicotianae & Pepper \\
\hline & $\mathrm{Com}-\mathrm{C} 2^{\mathrm{b}}$ & $\begin{array}{l}\text { Vineyard pruning } \\
\text { wastes }\end{array}$ & $\begin{array}{l}\text { Pepper } \\
\text { waste + arti- } \\
\text { choke waste }\end{array}$ & - & P. nicotianae & Pepper \\
\hline & $\mathrm{Com}-\mathrm{C} 3^{\mathrm{b}}$ & $\begin{array}{l}\text { Vineyard pruning } \\
\text { wastes }\end{array}$ & $\begin{array}{l}\text { Pepper } \\
\text { sludge + pepper } \\
\text { waste + garlic } \\
\text { waste + carrot } \\
\text { waste + almond } \\
\text { shells }\end{array}$ & - & P. nicotianae & Pepper \\
\hline & Com-C $4^{b}$ & $\begin{array}{l}\text { Vineyard pruning } \\
\text { wastes + com- } \\
\text { post }\end{array}$ & $\begin{array}{l}\text { Artichoke } \\
\text { sludge + arti- } \\
\text { choke waste }\end{array}$ & - & P. nicotianae & Pepper \\
\hline \multirow{3}{*}{$\begin{array}{l}\text { Traditional } \\
\text { composts } \\
\text { from } \\
\text { municipal } \\
\text { bio-waste }\end{array}$} & $\mathrm{Com}-\mathrm{H}^{\mathrm{a}}$ & - & - & Urban bio-waste & \multirow{3}{*}{$\begin{array}{l}\text { Fusarium oxysporum } \\
\text { f. sp. melonis } \\
\text { F.oxysporum } \\
\text { f. sp. lycopersici } \\
\text { F. oxysporum } \\
\text { f. sp. basilici }\end{array}$} & \multirow{3}{*}{$\begin{array}{l}\text { Melon } \\
\text { Tomato } \\
\text { Basil }\end{array}$} \\
\hline & $\mathrm{Com}_{-1} \mathrm{a}^{\mathrm{a}}$ & - & - & Wet bio-waste & & \\
\hline & Com- $L^{a}$ & - & - & $\begin{array}{l}\text { Cow } \\
\text { manure + house- } \\
\text { hold waste }\end{array}$ & & \\
\hline
\end{tabular}

quality and accumulation, Pseudomonas community structure and disease suppression under greenhouse condition using Illumina. Other authors have documented the disease-suppressive impact of new microbiome profiles after long-term supplementation of OAs [133]. Particularly, they observed significant microbiome changes using Illumina HiSeq sequencing that resulted to be very consistent in suppressing pepper blight disease by
P. capsici. They demonstrated that suppression of pepper blight was primarily due to antagonistic action of populations of Bacillus spp. in rhizosphere during the recruitment process of beneficial microorganisms from pepper plant into top soil. Other authors have instead compared the different chemical properties and the microbiome shifts using Illumina in different rhizosphere samples coming from the $F$. oxysporum-non-infested soil, $F$. 
Table 3 Amplicon sequencing platforms for identifying the biocontrol-based microbiota of the composts showed in Table 2

\begin{tabular}{|c|c|c|c|c|}
\hline Compost item & Suppressive model & Amplicon sequencing platform & Primer & References \\
\hline Green composts\# 1 & $\begin{array}{l}\text { Multi-suppressive } \\
\text { (both general and } \\
\text { specific) }\end{array}$ & $\begin{array}{l}\text { Amplicon sequencing of the bacterial } \\
16 S \text { rDNA gene and the fungal ITS1 } \\
\text { and ITS2 regions of the ITS rDNA } \\
\text { gene. Trichoderma is identified by } \\
\text { sequencing the ITS1-5.8S-ITS2 gene } \\
\text { regions of the rDNA }\end{array}$ & $\begin{array}{l}\text { Multiple primer pairs sets for bacteria } \\
\text { 8F/120R, 388F/534R, 968F/1073R and } \\
\text { 8F/361R } \\
\text { Universal primer pairs sets for fungi } \\
\text { ITS5F/ITS2R and ITS3F/ITS4R } \\
\text { Universal primer pairs sets for Tricho- } \\
\text { derma: ITS1F/ITS4R } \\
\text { Primer pairs for Trichoderma harzi- } \\
\text { anum, Trichoderma } \\
\text { Asperellum and Trichoderma atroviride } \\
\text { Chit42-1a and Chit42-2a }\end{array}$ & De Corato et al. [55] \\
\hline Green composts\#2 & General & $\begin{array}{l}\text { Amplicon sequencing of the bacterial } \\
16 S \text { rDNA gene and the fungal ITS1 } \\
\text { and ITS2 regions of the ITS rDNA } \\
\text { gene. Trichoderma is identified by } \\
\text { sequencing the ITS1-5.8S-ITS2 gene } \\
\text { regions of the rDNA }\end{array}$ & $\begin{array}{l}\text { Multiple primer pairs sets for bacteria } \\
\text { 8F/120R, 388F/534R, 968F/1073R and } \\
\text { 8F/361R } \\
\text { Universal primer pairs sets for fungi } \\
\text { ITS5F/ITS2R and ITS3F/ITS4R } \\
\text { Universal primer pairs sets for Tricho- } \\
\text { derma ITS1F/ITS4R } \\
\text { Primer pairs for Trichoderma harzi- } \\
\text { anum, Trichoderma } \\
\text { Asperellum and Trichoderma atroviride } \\
\text { Chit42-1a and Chit42-2a }\end{array}$ & De Corato et al. [55] \\
\hline Green composts\#3 & General & $\begin{array}{l}\text { Amplicon sequencing of the bacte- } \\
\text { rial 16S rRNA gene and the fungal } \\
\text { ITS1 and ITS2 regions of the ITS } \\
\text { rRNA gene using lon Torrent PGM } \\
\text { sequencing }\end{array}$ & $\begin{array}{l}\text { Multiple primer pairs sets for bacteria } \\
\text { 8F/120R, 388F/534R, 968F/1073R and } \\
\text { 8F/361R } \\
\text { Universal primer pairs for fungi } \\
\text { ITS5F/ITS2R and ITS3F/ITS4R }\end{array}$ & Blaya et al. [22] \\
\hline $\begin{array}{l}\text { Traditional composts } \\
\text { from municipal bio- } \\
\text { waste }\end{array}$ & Specific & $\begin{array}{l}\text { Amplicon sequencing of the bacterial } \\
16 S \text { rDNA gene and the fungal ITS1 } \\
\text { and ITS2 regions of the ITS rDNA } \\
\text { gene. Trichoderma is identified by } \\
\text { sequencing the ITS1-5.8S-ITS2 gene } \\
\text { region of the rDNA }\end{array}$ & $\begin{array}{l}\text { Multiple primer pairs sets for bacteria } \\
\text { 8F/120R, 388F/534R, 968F/1073R and } \\
\text { 8F/361R } \\
\text { Universal primer pairs sets for fungi } \\
\text { ITS5F/ITS2R and ITS3F/ITS4R } \\
\text { Universal primer pairs sets for Tricho- } \\
\text { derma ITS1F/ITS4R } \\
\text { Primer pairs for Trichoderma harzi- } \\
\text { anum, Trichoderma asperellum and } \\
\text { Trichoderma atroviride Chit42-1a and } \\
\text { Chit42-2a }\end{array}$ & De Corato et al. [55] \\
\hline
\end{tabular}

oxysporum-infested soil and watermelon-waste-amended soil to assess the potential role of the new microbiome in plant health and Fusarium wilt suppression in a watermelon cropping system [158]. Other study has showed by Illumina the soil microbial communities' shifts either inducing a Rhizoctonia-disease-inoculum reduction or perturbing the agronomic traits of wheat crop by beneficial and detrimental interactions in the soil, respectively, where the microbial communities resulted to be significantly changed after inoculation of the Streptomyces biocontrol strains to wheat seeds [7]. Finally, as last relevant case study, it is due to underline the beneficial effects of the microbiota recruited from the rhizosphere of a soil amended with disease-suppressive green composts either on the plant fitness (vegetative growth and productivity) or on the root protection against Fusarium and Verticillium wilts in a tomato cropping system, although using the Terminal-Restriction Fragment
Length Polymorphism (T-RFLP) rather than Illumina sequencing [6].

On the other hand, several agronomical practices as the land-use management, different tillage systems and different fertilization practices have also enhanced suppression against soil-borne pathogens (Table 4). At this regard, stability of the soil bacterial community along the seasonal changes, overall in spring and autumn under different land-use management in Mediterranean agroecosystems, have been assessed by T-RFLP [19]. Finally, to evaluate the fungal community shifts for suppressing fusaria root rot of wheat, more investigation on the impacts of different tillage systems (strip tillage vs. conservation tillage) and fertilization practices (intensive vs. extensive) in two crop rotation systems (winter wheat-maize vs. winter wheat-rapeseed) were established by Illumina in a long-term field trial [199]. 


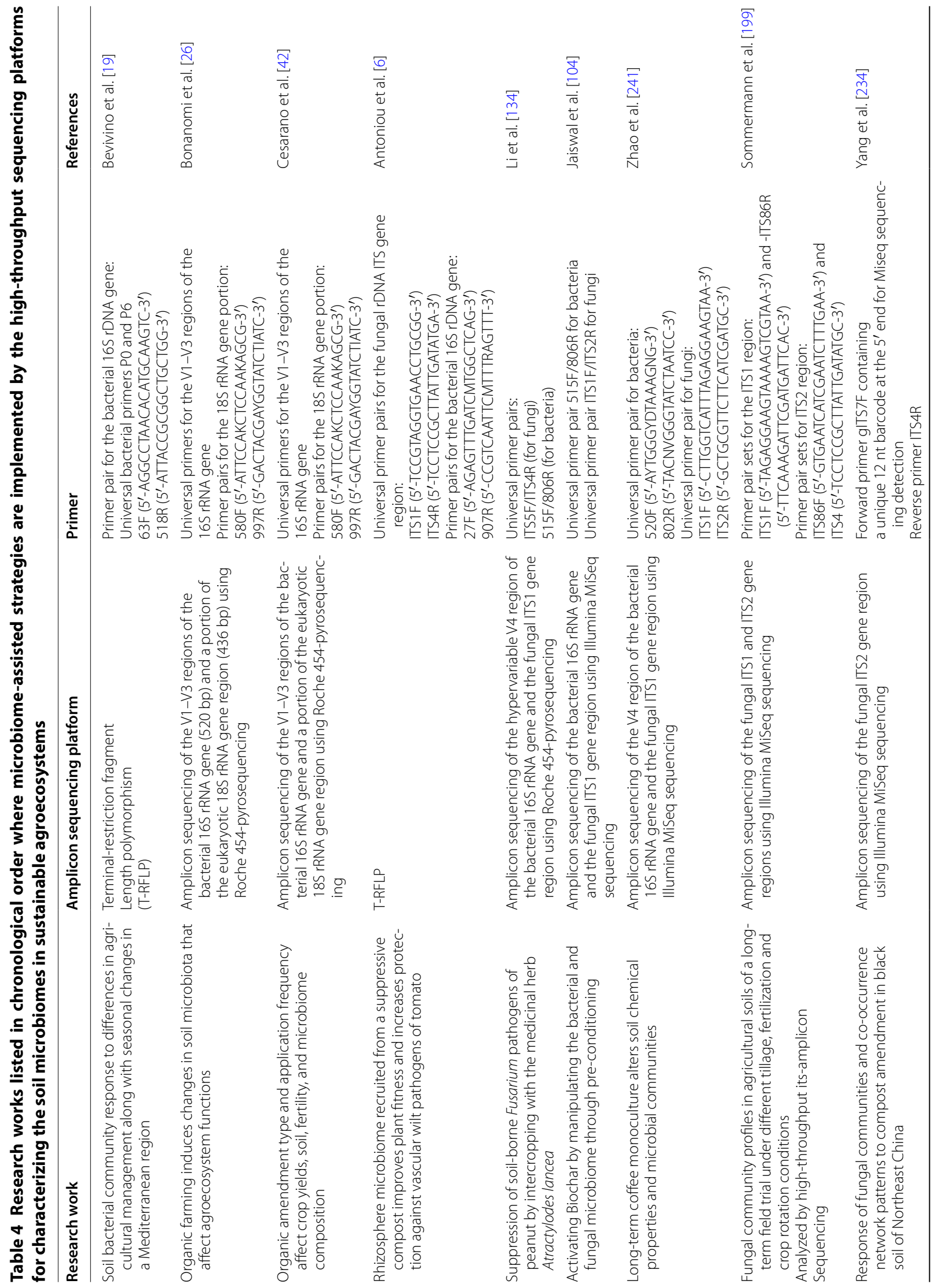




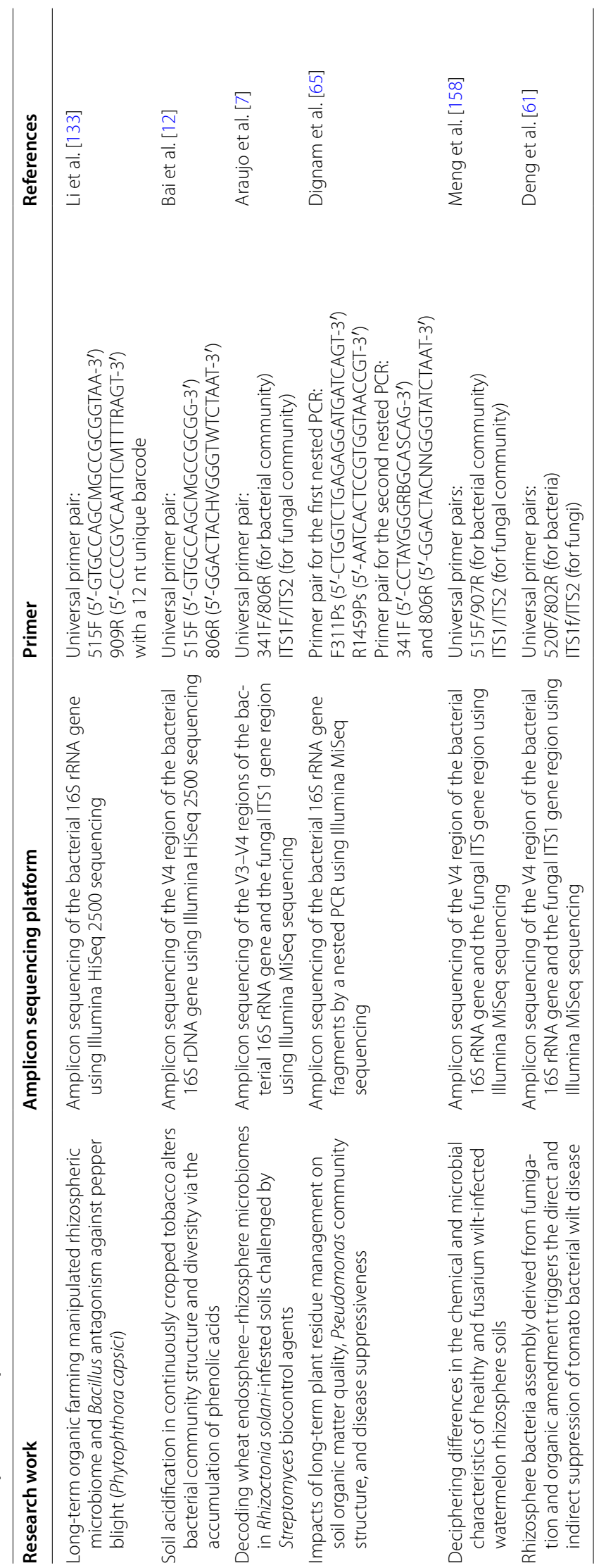




\section{The best agronomical practices for increasing soil disease suppression by the new microbiome-assisted strategies}

To the best agronomical practices for increasing soil disease suppression under the light of the new microbiomeassisted strategies, the underlying soil management items seemed to be the most reliable.

\section{Soil management by amendment with disease-suppressive compost}

Soil management by amendment with tailored diseasesuppressive composts from green wastes resulted to be a consolidated strategy that induces significant shifts of the soil microbiota toward beneficial consortia for effectively controlling soil-borne pathogens [45, 54, 149, 154]. This paper focusses its interest on the most recent findings related to a next-generation composts' collection (Table 2) coming from green sources (plant wastes, agroindustrial residues and agro-wastes) and wet biomass wastes (municipal organic solid waste and co-composted animal manure with household waste).

De Corato et al. [55] have determined abundance, richness and diversity, as well as relationships among the fungal and bacterial communities of composts by amplicon sequencing (Table 3). In general, differences in the taxonomic structure were related to feedstock composition. In particular, green composts from agro-wastes and agro-industrial co/by-products provided the most varied and complex microbiomes related to suppression of Rhizoctonia damping-off of bean and pea, Verticillium wilt of eggplant, Pythium damping-off of cucumber and melon, and Phytophthora root rot of tomato and azalea. Composts from differentiated municipal organic solid waste and co-composted cow manure with household waste were instead prevalently colonized by microbiota related to suppression of Fusarium wilt of melon, tomato and basil. The amplicons resulted affiliated to the genus Trichoderma in suppressing $R$. solani damping-off of bean and pea; Aspergillus, Penicillium, Streptomyces and fluorescent Pseudomonas in suppressing F. oxysporum wilt of melon, tomato and basil; Bacillus and fluorescent Pseudomonas in suppressing V. dahliae wilt of eggplant. Suppression of Pythium damping-off of cucumber and melon, and Phytophthora root rot of tomato and azalea was instead strictly correlated to the increased biological activity of the composts determined by the increased abundance, richness and diversity of the microbial consortia identified at phylum level (Fig. 1a, b). This study has demonstrated that amplicon sequencing resulted to be a reliable and faster approach for characterizing the fungal and bacterial microbiomes up to species level (only for certain genus) into a collection of disease-suppressive composts. In this study, fungal amplicons (Fig. 2a, b) were related to suppression of restrict groups of soilborne pathogenic fungi. In particular, the increased population of Trichoderma identified sequencing the ITS1-5.8S-ITS2 gene regions of the rDNA [225] resulted to be consistent in green composts, as well as populations of T. harzianum, T. asperellum and Trichoderma atroviride identified by amplification of the chitinase gene region [4, 121]. Moreover, the increased population of Mortierella sp. was noticeable in the microbial communities associated with the suppression of Fusarium wilt of melon, tomato and basil. This finding was confirmed by previous molecular-based studies performed by Illumina revealing that Fusarium wilt of vanilla was predominantly suppressed by a significant abundance of Mortierella in soil [228]. The genus Mortierella has recently been considered as a key biotic factor for fusaria wilt suppression where the order Mortierellales is known as the primary indicator of disease suppression in vanilla [228]. Likely, bacterial amplicons (Fig. 2c) were related to suppression of specific soil-borne pathogenic fungi. Abundance of key taxa such as Pseudomonadales (overall fluorescent pseudomonads), Bacillales (overall species of Bacillus and Paenibacillus) and Streptomycetales (overall species of Streptomyces) conferring a stronger suppressiveness against phytopathogens resulted was consistent with composts. Amplicon sequencing was also used to evaluate abundance (Fig. 3a), richness (Fig. 3b) and diversity (Fig. 3c) of the fungal and bacterial communities in composts acting in synergism against soil-borne phytopathogens. A very rich and diversified microbiome, overall if compared to those revealed by microbial culture-based enrichment methods [57], was found in green compost.

Blaya et al. [22] have instead evaluated the microbial structure of disease-suppressive composts from green wastes (Table 2) showing different suppressiveness degrees to $P$. nicotianae in pepper using Ion Torrent sequencing (Table 3). Unlikely to the findings of De Corato et al. [55], although the microbiota of these disease-suppressive green composts has been identified up to genus level, at the most, it showed however higher correlations with the suppression attributes than traditional composts.

\section{Soil management by pre-fumigation combined with supplementation of $O A s$ and bio-fertilizers}

Soil management by pre-fumigation with eco-friendly molecules in combination with fortified bio-organic fertilizers (Table 4) is considered an innovative strategy that can trigger significant microbiota changes for effectively controlling soil-borne pathogens [61]. These authors have questioned that any efficient method was widely recognized for controlling and/or preventing bacteria wilt of 


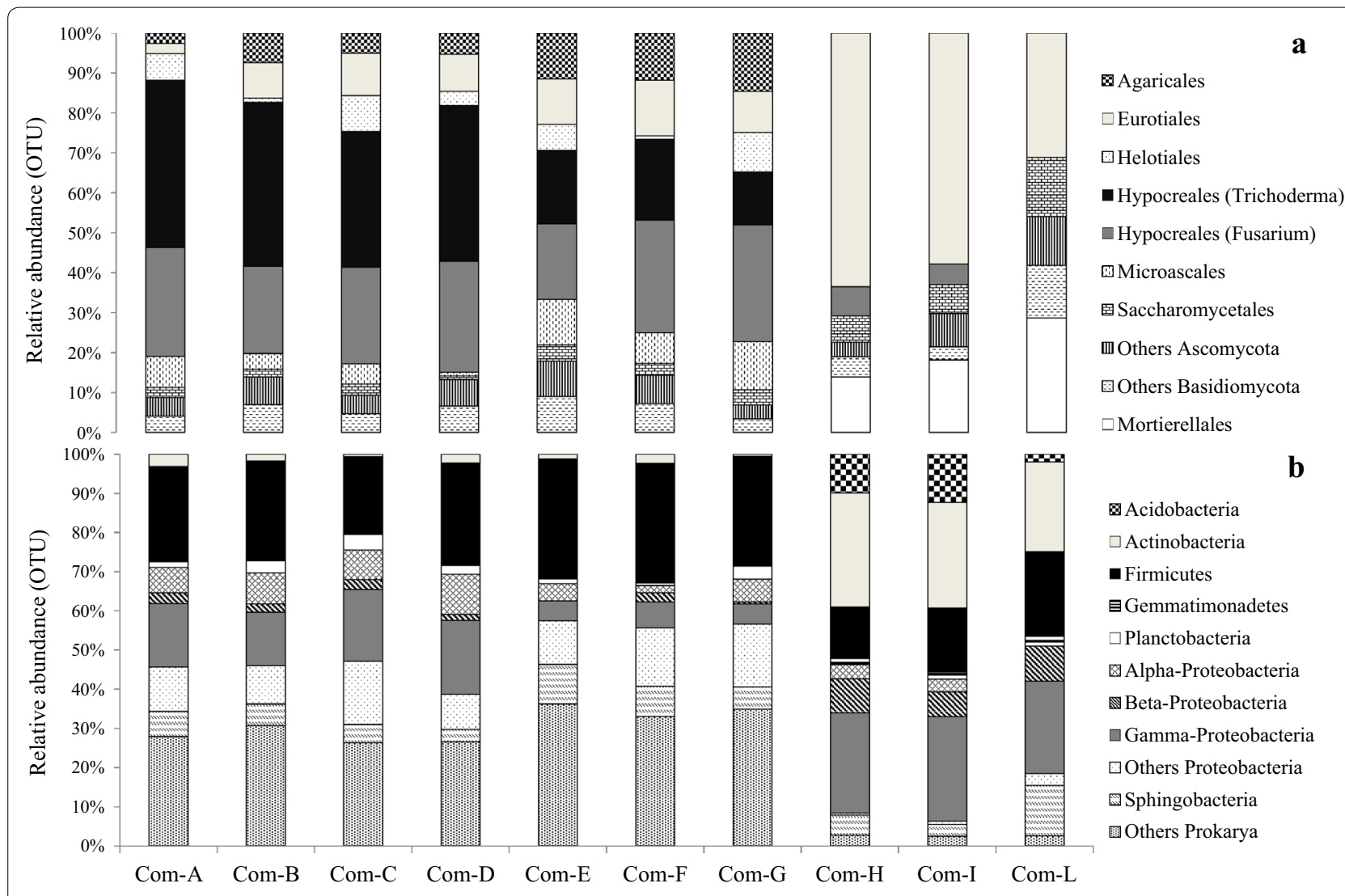

Fig. 1 Typical compositional bars plot showing the relative abundance of a fungi and $\mathbf{b}$ bacteria, expressed as operational taxonomic units (OTUs) percentage, identified in 10 suppressive composts at phylum and order levels (for fungi) and phylum and class levels (for bacteria) using amplicon

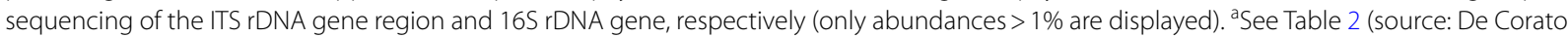
et al. [55])

tomato caused by Ralstonia solanacearum. Treating of soil in a tomato field naturally affected by Ralstonia wilt using four types of treatment, and then evaluating the outcomes of disease incidence and severity in response to the treatments, these authors effectively control wilt disease without use of synthetic fumigants. All treatments had one of two bio-organic fertilizers, each with or without soil pre-fumigation. These authors found that soil pre-fumigation resulted in a very strong reduction of severity and incidence of the wilt disease. Afterward, they have gone through on the amplicon sequencing patterns to evaluate the soil microbial community structures before and after treatment using Illumina MiSeq sequencing. Basing on their findings, they presented an interesting hypothesis on how soil pre-fumigation, if combined with OAs, resulted in a microbiota restructuring by two main steps. In the first one, pre-fumigation destroys the wild microbiota; afterward, setting the further stages of soil colonization by use of OAs and bioorganic fertilizers, it can be reached more benefit for soil-supplying beneficial microbiota to suppress bacteria wilt. This study provides new insights based on the combined use of soil pre-fumigation with an eco-friendly nitrogen-based substance (ammonium bicarbonate) and compost-fortified bio-organic fertilizers to reduce disease incidence and severity of Ralstonia wilt. This combined strategy effectively controls tomato bacterial wilt disease despite a high abundance of $R$. solanacearum in soil. The impact of treatments on the soil microbiomes as well as the mechanism leading to disease suppression were both investigated. The combined treatment of pre-fumigation by ammonium bicarbonate with compost-fortified bioorganic fertilizers has led to significant change in the soil bacterial and fungal communities. Fumigation and organic amendment equally affected the microbiome variation in the rhizosphere at harvest time. Further, the shifts of the bacterial community in rhizosphere acted as a key factor for controlling Ralstonia wilt of tomato. In addition, the bacterial genera Rhodanobacter, Terrimonas and Chitinophaga identified in rhizosphere after 

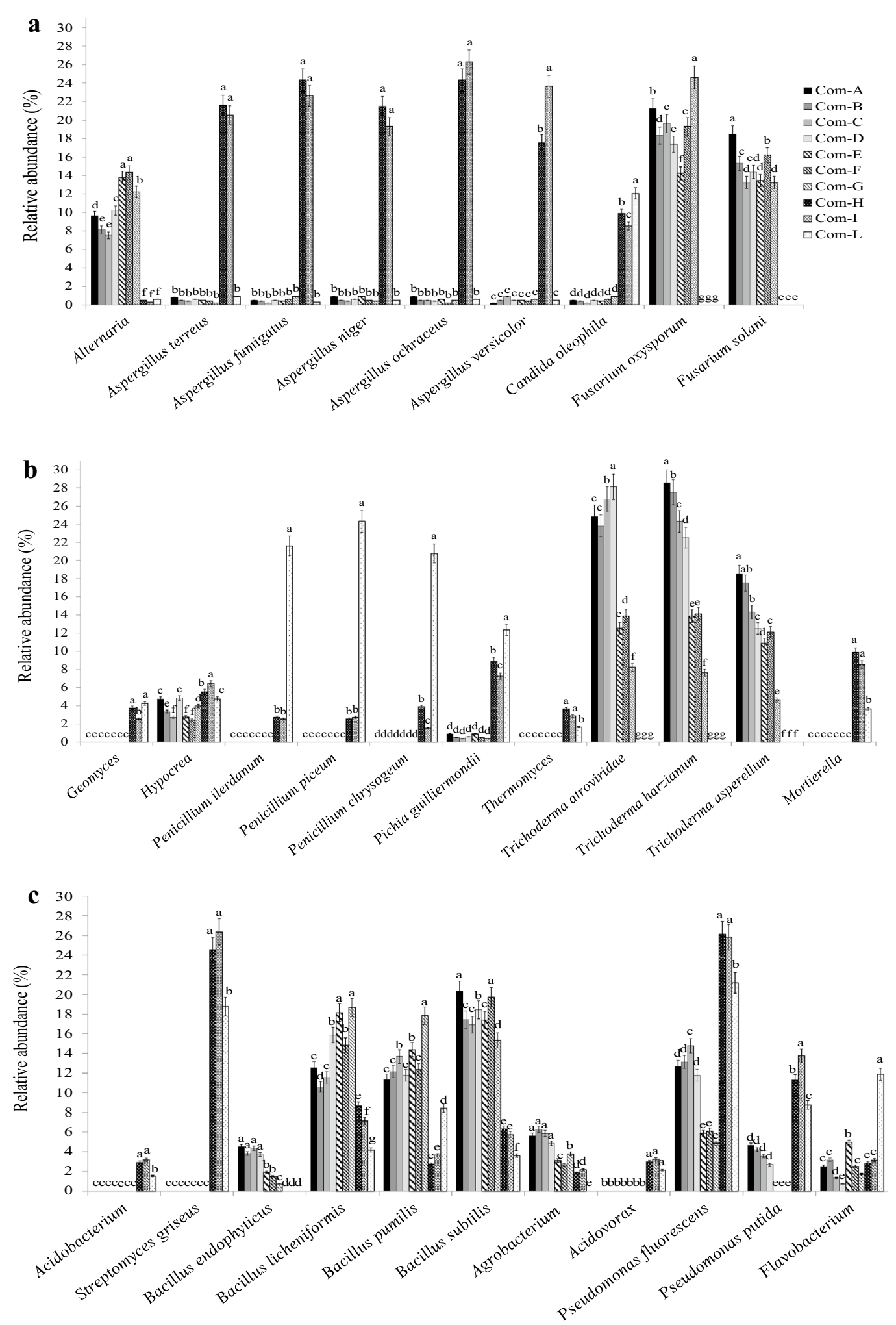

Fig. 2 Typical bars chart showing the relative abundance of $\mathbf{a}, \mathbf{b}$ fungi and $\mathbf{c}$ bacteria (expressed as high-quality sequences percentage) identified in 10 suppressive composts ${ }^{a}$ at genus and species levels using amplicon sequencing of the ITS rDNA gene region and 165 rDNA gene, respectively (only abundances $>0.1 \%$ are displayed). ${ }^{a}$ See Table 2 (source: De Corato et al. [55]) 

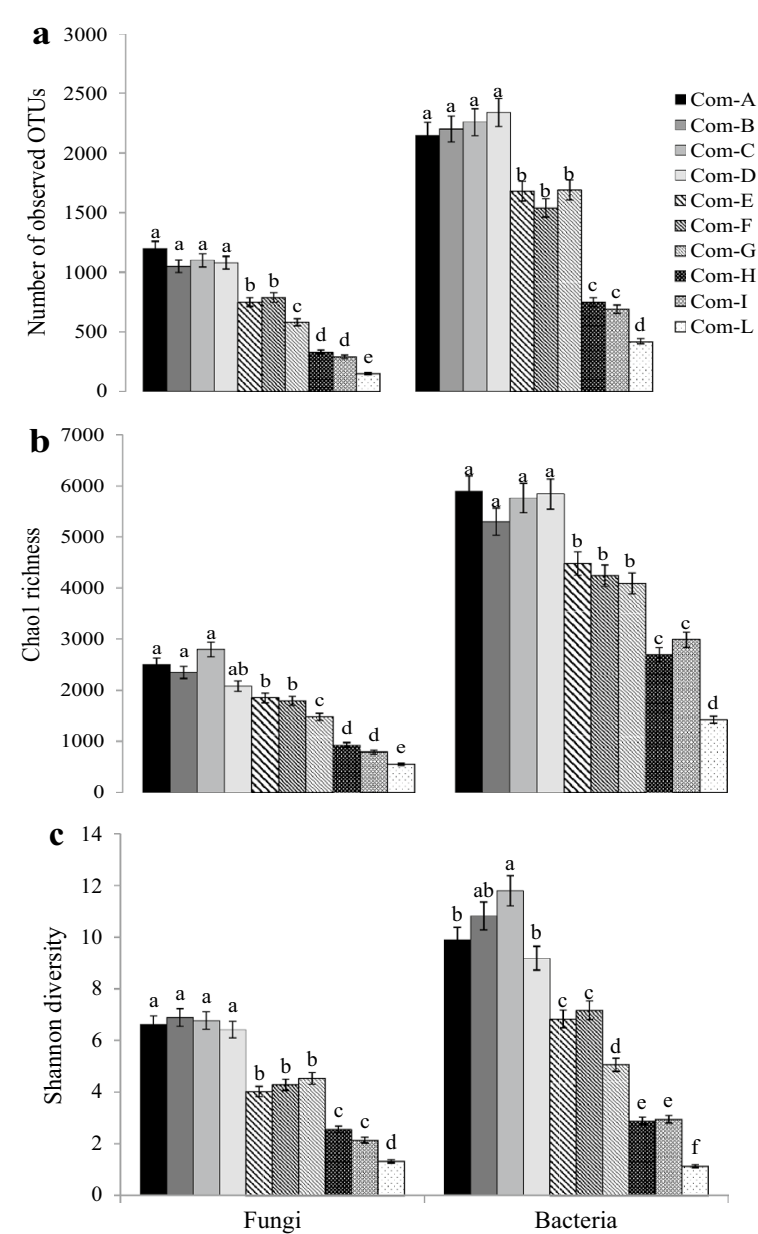

Fig. 3 Typical bars chart showing the alpha-diversity indices of the fungal and bacterial communities in 10 suppressive composts ${ }^{\mathrm{a}}$ indicating $\mathbf{a}$ the number of observed OTUs, $\mathbf{b}$ Chao 1 richness and $\mathbf{c}$ Shannon diversity using amplicon sequencing of the ITS rDNA gene region and $16 \mathrm{~S}$ rDNA gene, respectively. ${ }^{2}$ See Table 2 (source: De Corato et al. [55])

soil treatments were associated to new potential key taxa related to suppression of pathogenic soil-borne bacteria. Thus, fumigation and organic amendment determined disease suppression either directly, decreasing the abundance of $R$. solanacearum in soil, or indirectly, altering bacterial composition with the increased growth of bacterial taxa [61].

Despite these encouraging findings, other studies that employed BCAs, OAs and fortified bio-fertilizers to plant seeds and/or roots showed that these beneficial microorganisms do not last for long time (months or years) in the rhizosphere or within the plant microbiome, but only lasting for some weeks, at the least. The two main questions that should be raised by the users are the following: (i) Can any strategies be used to preserve relevant BCAs' abundance in the rhizosphere for longer times even if added artificially in multiple times? (ii) Can the protective effects against soil diseases persist for months, or even years, without further amendments? These are the two fundamental questions that should be taken account before adopting this integrated strategy on large scale according to Bonanomi et al. [24].

\section{Soil management by crop rotation and intercropping}

Soil management by crop rotation and intercropping was both considered suitable strategies for effectively controlling soil-borne pathogens. More studies on the detrimental effects of monoculture-based systems on the microbiome patterns have been performed using Illumina MiSeq sequencing (Table 4). In this regard, authors have investigated how long-term coffee monoculture both affects the soil chemical properties and microbiota composition determining serious economic losses in China [241]. They found that a severe inhibition of the coffee plant growth and a significant yield decreasing were related with the increased abundance of fusaria wilts and fusaria-related pathogens, overall with the reduced abundance and diversity of the soil fungal and bacterial communities. Other authors have studied how long-term tobacco monocultures induced soil acidification due to accumulation of phenolic acids and severe alterations of the beneficial bacterial community in terms of abundance, structure and diversity using Illumina HiSeq sequencing [12]. In fact, it is well known that increasing the plant pathogens populations and decreasing the beneficial soil-derived microbes populations have determined severe detrimental effects in many soils managed under monoculture systems [135, 142, 146, 166].

Crop rotation can help to mitigate disease incidence and severity in many cropping systems by changing the soil fungal community structure along the rhizosphere profile [229]. Authors have studied, for example, the beneficial effects of the crop rotation cherry tomato-durum wheat vs. tomato monoculture on Fusarium wilt suppression and tomato shoot growth in an Italian tomato cropping system under open field condition by supplementation of disease-suppressive compost [54]. Overall analyzing abundance, composition, richness and diversity of fungal and bacterial communities by Illumina MiSeq sequencing including the understanding of the relationships among soil chemical parameters, disease suppression and the microbiomes, it has been established that certain microorganisms associated to biocontrol of $F$. oxysporum of tomato can consistently increase at the end of rotation period carried out for at least 4 consecutive years with durum wheat. Fluctuations of the soil microbial communities during the rotation tomato-wheat on Fusarium wilt suppression were consistently detected. The microbiome 
shifts primarily depend on the adopted crop rotation system that may have a great potential for enrichment (or preservation) of the saprophytic microbial consortia supplied by compost and related to fusaria-related wilts suppression such as bacteria (Bacillus, Paenibacillus and Pseudomonas), actinomycetes (Streptomyces) and filamentous fungi (Aspergillus, Penicillium and Mortierella). These findings (unpublished observations) are in agreement with those of Liu et al. [137] in a Chinese cropping system based on the cherry tomato-rice rotation. Other authors have confirmed a significant decrease in incidence and severity of fusaria-related wilts for soils managed under different crop rotation systems. A relevant amount of data are available to well understand how the fungal and bacterial communities can operate in synergism to suppress diseases by several mechanisms [31, 140, 240]. Among them, the most accredited hypotheses about the beneficial effects of the crop rotation on, for example, soil suppression of $F$. oxysporum of tomato were related to their modulatory effects provoked by the tillage-crop rotations on the shifts of certain beneficial soil-derived bacteria and fungi associate to the roots of the host [108, 163, 205, 218, 230, 236].

Likely to crop rotation, intercropping can also help to mitigate disease incidence and severity in some cropping systems by changing the soil microbiome structure. Li et al. [133] have studied the suppressive role of volatiles and exudates from rhizome and root of the medicinal herb Atractylodes lancea on fungal and bacterial communities in controlling Fusarium root rot of peanut using Roche 454-pyrosequencing (Table 4). Intercropping peanut with A. lancea was significantly enhanced the richness and diversity of the fungal community in the peanut rhizosphere that coincided with the decline of Fusarium root rot and improvement of peanut growth in comparison to peanut monoculture. The authors suggested that intercropping peanut with $A$. lancea becomes effectively suppressed Fusarium diseases of peanut resulting in the increased peanut yield. They highlighted that $A$. lancea altered the fungal community composition in the peanut rhizosphere more than the bacterial community. Volatiles originating from $A$. lancea rhizome had more stimulating effects on the beneficial fungal community than those bacterial, thus Fusarium root rot of peanut was significantly suppressed. Exudates originating from $A$. lancea root had instead no apparent inhibitory effect on Fusarium root rot of peanut.

\section{Critical comparison and advancements of NGS technology for characterizating soil microbiota in agriculture}

Comparing the amplicon HTS platforms in relation to the findings aforementioned, those of 1st and 2nd generation have given a series of processing data that allowed larger genomes sequencing in shorter time than traditional amplicon sequencing. In the "new era" of the MiSeq and HiSeq platforms, Illumina seemed to be more performing than Roche 454-pyrosequencing because it processes more operations (clonal amplification, genomic DNA sequencing and data analysis with base calling, alignment, variant calling and reporting) in a single sequencing run. However, a critical comparison of Illumina vs. Roche 454-pyrosequencing is done. A review study [143] concluded that the Roche 454 FLX + Titanium system has higher error rate in homo-polymer regions (three or more consecutive identical DNA bases) caused by accumulated light intensity variance than the Illumina Genome Analyzer (GA) II system [148, 182]. Moreover, up to $15 \%$ of the resulting sequences are represented by artifacts and false-positives [74]. Despite the substantial differences in read length and sequencing protocols, the two platforms provided a comparable overview of the community sampled [143]. In addition, more information concluded that Illumina is a better option vs. 454-pyrosequencing for different reasons (unpublished observations). First, although Illumina costs more to run the machine, the number of sequences processed by it is much greater vs. Roche 454. In fact, Illumina costs over 2-3 times Roche 454, but it gives an amount of data for over 10 times than Roche 454. Second, the quality filtering data in Illumina are simpler than Roche 454 and do not need worry about the artifacts coming from the homo-polymer runs. Third, if doing amplicon sequencing, the getting overlap between your forward and reverse sequences allows for a more stringent quality control. Fourth, Roche 454-pyrosequencing is discontinued from 2016. Thus, if researchers are looking for a long-term platform, Roche 454 should not be a better option; if researchers think to only need for a short time period of sequencing, Illumina should not be the best option because it requires a relevant amount of investment in getting laboratory protocols optimized in shorter time; if researcher groups are planning to do weekly or monthly a very much lot of amplicon sequencing runs, Illumina should be more long-lasting option. As last consideration, it can notice that an improved dual-indexing approach for multiplex $16 \mathrm{~S}$ rRNA gene sequencing is available by Illumina MiSeq platform [76].

The third-and fourth-generation sequencing platforms have been developed for agricultural purposes only in the recent years. For soil microbiome studies, ion semiconductor sequencing performed by the Ion Torrent/ Ion Proton platforms is a method of DNA sequencingbased on the detection of hydrogen ions (protons) that are released during the polymerization of DNA. Likely to Illumina, Ion Torrent is a method of "sequencing by synthesis" during which a complementary strand is built 
based on the sequence of a template strand. This technology differs from Illumina in that no modified nucleotides or optics are used. Ion semiconductor sequencing includes different platforms as Ion Torrent sequencing, $\mathrm{pH}$-mediated sequencing, silicon sequencing and semiconductor sequencing. Also, for soil microbiome studies, the Oxford Nanopore platform by mini flow cells $\left(\right.$ MinIon $^{\mathrm{TM}}$ ) and PacBio are both based on ionic readings that potentially could become competitive due to their high capability to sequence up to 1000 kilobases per millisecond without the need of DNA amplification [30, 197]. Although these novel platforms at high-resolution level of phylogenetic microbial community profiling are potentially promising since they combine their easy use and portability with a massive data production, nonetheless they are less used than others because they still have too many sequencing errors. This could be a reason why they are not currently useful for metagenomics studies (personal communications). Table 5 provides a summary of the most commonly used HTS platforms for characterizing the soil microbiomes. Despite encouraging advancements, the researcher which currently uses Illumina and Ion Torrent can determine just the family and genus levels of microbiota, at the most, so excluding from their issues the species and strain levels. Nonetheless, Illumina seems to be the fastest approach for identifying fungal and bacterial consortia from soil, rhizosphere, compost, OAs, bio-fertilizer and biochar.

A recent work evaluated the possibility of sequencing the 16S rRNA gene for bacterial species and strain-level in microbiome analysis [109]. This study aimed at critically re-evaluating the potential use of the $16 \mathrm{~S}$ gene to provide the highest taxonomic resolutions at species and strain levels. These authors demonstrated that targeting the $16 \mathrm{~S}$ variable regions with short-read sequencing platforms cannot be achieved the same taxonomic resolution afforded by sequencing the entire gene. They affirmed that full-length sequencing platforms are sufficiently accurate to resolve subtle nucleotide substitutions (but not insertions or deletions) that exist between intragenomic copies of the $16 \mathrm{~S}$ gene. They concluded that modern analysis approaches must necessarily account for intra-genomic variation between $16 \mathrm{~S}$ gene copies. In particular, they demonstrated that appropriate treatment of full-length $16 \mathrm{~S}$ intra-genomic copy variants has the potential to provide a better taxonomic resolution of bacterial communities at species and strain levels.

Moreover, it is due to underline that there are multiple primers at high coverage that cover a $100 \%$ similarity from different microbial species due to the lack of diversity in the partial gene sequence. For instance, there are conservative fragments in bacterial 16S rRNA genes and primers designed for $16 \mathrm{~S}$ rDNA amplicons in metagenomics studies [220]. Researchers use multiple primer pairs that cover different area of the $16 \mathrm{~S}$ in Illumina sequencing analysis of soil bacterial communities. The 16S rDNA gene has been amplified in many studies using the 8F/120R, F388/R534, F968/R1073 and 8F/ R361 primer pairs for giving a better taxonomic resolution of the bacterial community at species level $[6,201]$. Also, a better taxonomic resolution of fungal communities has been reached sequencing the ITS1 gene region by the ITS1/ITS4, ITS2/ITS5 and ITS3/ITS4 primer pairs that provided higher taxonomic resolution up to species level for characterizing fungal community $[6,225]$. Moreover, ITS primers with an improved specificity for

Table 5 Comparison of the most commonly used high-throughput sequencing platforms for characterizing the soil microbiomes. Source: Jagadeesan et al. [103]

\begin{tabular}{|c|c|c|c|c|c|c|c|c|}
\hline Platform ${ }^{a}$ & Generation & $\begin{array}{l}\text { Sequencing } \\
\text { technology }\end{array}$ & Read length & Output/run & $\begin{array}{l}\text { Error } \\
\text { rate }\end{array}$ & $\begin{array}{l}\text { Example } \\
\text { of use }\end{array}$ & $\begin{array}{l}\text { Type } \\
\text { of instrument } \\
\text { and run time }\end{array}$ & $\begin{array}{l}\text { Taxonomic } \\
\text { resolution } \\
\text { level }\end{array}$ \\
\hline Illumina & $\begin{array}{l}\text { Second gen- } \\
\text { eration }\end{array}$ & $\begin{array}{l}\text { Sequencing by } \\
\text { synthesis }\end{array}$ & $\begin{array}{l}\text { Short reads } \\
1 \times 36 b p-2 \times 300 b p\end{array}$ & $0.3-1000 \mathrm{~Gb}$ & Low & Variant calling & $\begin{array}{l}\text { Benchtop } \\
2-29 h\end{array}$ & Low-resolution \\
\hline Ion Torrent & $\begin{array}{l}\text { Third genera- } \\
\text { tion }\end{array}$ & $\begin{array}{l}\text { Sequencing by } \\
\text { synthesis }\end{array}$ & $\begin{array}{l}\text { Short reads } \\
200-400 \mathrm{bp}\end{array}$ & $0.6-15 \mathrm{~Gb}$ & Low & Variant calling & $\begin{array}{l}\text { Benchtop } \\
2-4 \mathrm{~h}\end{array}$ & Low-resolution \\
\hline PacBio & $\begin{array}{l}\text { Fourth genera- } \\
\text { tion }\end{array}$ & $\begin{array}{l}\text { Single } \\
\text { molecule } \\
\text { sequencing } \\
\text { by synthesis }\end{array}$ & $\begin{array}{l}\text { Long reads } \\
\text { up to } 60 \mathrm{~kb}\end{array}$ & $0.5-10 \mathrm{~Gb}$ & High & $\begin{array}{l}\text { De novo } \\
\text { assembly of } \\
\text { small bacte- } \\
\text { rial genomes } \\
\text { and large } \\
\text { genome } \\
\text { finishing }\end{array}$ & $\begin{array}{l}\text { Large scale } \\
0.5-4 \mathrm{~h}\end{array}$ & High-resolution \\
\hline $\begin{array}{l}\text { Oxford Nano- } \\
\text { pore }\end{array}$ & $\begin{array}{l}\text { Fourth genera- } \\
\text { tion }\end{array}$ & $\begin{array}{l}\text { Single mol- } \\
\text { ecule }\end{array}$ & $\begin{array}{l}\text { Long reads } \\
\text { up to } 100 \mathrm{~kb}\end{array}$ & $0.1-20 \mathrm{~Gb}$ & High & $\begin{array}{l}\text { Complete } \\
\text { genome of } \\
\text { isolates and } \\
\text { metagenom- } \\
\text { ics }\end{array}$ & $\begin{array}{l}\text { Portable } \\
1 \mathrm{~min}-48 \mathrm{~h}\end{array}$ & High-resolution \\
\hline
\end{tabular}

\footnotetext{
a Roche 454-pyrosequencing (First-generation platform) is discontinued from 2016
} 
basidiomycetes (overall mycorrhizae and rusts) are yet available since 1990s [79].

To fully describe role and functionality of the soil microbiota, it must be recalled that amplicon sequencing is not itself enough to understand the complex biological processes that take place within the soil [21]. The phylogenetic characterization of prokaryotic cells based on DNA extraction from soil does not reflect the real activity of soil microbiome since DNA may be extracted from dead or inactive cells. Moreover, the provided information did not strongly contribute to our understanding of the impact of different microbiomes in agroecosystems for various reasons. These main limitations can be summarized as follows: (i) higher cost for soil analyses and complex bioinformatics pipelines; (ii) huge heterogeneity in space and the complex statistical techniques required to grasp this variation; (iii) temporal dynamics of soil microbiome; (iv) concentration of products/substrates of the target process that often overlooks the levels of these compounds in soil that may depend on the biotic/abiotic processes; and (v) taking into account that data generated by HTS do not provide any information on the total abundances of the identified clades. Thus, general recommendations and current guidelines for soil microbiome analyses should be available worldwide [131, 165].

\section{Concluding remarks}

Agroecosystems management is fundamental to ensure long-term persistence of ecosystem services under detrimental condition of the soils. Microbiota can increase the natural soil suppressiveness against soil-borne pathogens whenever soil properties and crop yields are progressively declining. Intensive cropping systems characterized by higher input of synthetic chemicals, lower SOM accumulation, scarce humification degree and frequent soil tillage are the primary reasons for soil depletion. Soil microbiota associated to BCAs is the key factor for plant health where more studies on soil microbiota disturbance by OAs, tailored microbe-based formulations, and BCAs' selected species/strains were reported since 2000s. Instead, very little attention has been paid on the ecological impact of beneficial microbial consortia recruited from compost, overall if associated with supplementation of exogenous BCAs of unknown origin. As well, little attention has been paid on the impact of crop rotation and intercropping, either alone or in combination with the soil pre-fumigation and compost/biochar supplementation. In this regard, the ecological roles of soil microbiota should be more in-depth elucidated in relation to a better understanding of the microbial community network inhabiting the soils.

Insights indicating what agronomical practices seemed to be the best approach to design novel cropping systems for increasing soil suppressiveness by microbiomeassisted management supported by NGS have been presented and critically discussed in this paper. The best agronomical practices for improving soil disease suppression under the light of new cropping systems can be implemented by use of tailored OAs and composts/biochar, and fortified bio-fertilizers that can shift wild microbiota of the soil toward beneficial microbial consortia based on disease suppression. In this regard, it can conclude that adopting tailored multi-suppressive composts in intensive horticultural cropping systems, if overall combined by crop rotation and intercropping with suitable crops (i.e., herbaceous medicinal species, rapeseed, rice, wheat, etc.) and soil pre-fumigation by eco-friendly molecules (i.e., ammonium bicarbonate or other nitrogen derivatives), can be reach the challenges in suppressing soil-borne diseases in sustainable agroecosystems.

The remaining open questions to a better understanding of the abundance, composition, richness, evenness and diversity of the biocontrol-based microbiota could be answered developing the best HTS platforms and bioinformatics pipelines basing on standardized analyses of the soil microbiomes. If the soil microbiomes can be quickly screened, more reliably characterized at the highest taxonomic resolution levels, and finally quantified in abundance, richness and diversity in shorter time, will be given in the near future useful ecosystem services for responding, at least partly, to the first three questions raised above. If from one hand it can conclude that Illumina can be still considered the best option for identifying soil microbial communities under disturbance of their microbiomes, on the other hand it can affirm that standardized procedures, recommendations and general guidelines for soil microbiome analyses should be urgently implemented. This review also aims to promote the use of NGS in organic agriculture highlighting the knowledge gaps and future research directions that need to augment the added-value generated from the application of NGS technology.

Concluding, it should be recalled again that the phylogenetic characterization of microbiota based on DNA analyses does not reflect the real biological activity of microbial community. In this perspective, the omics sciences combining the metagenomics, metatranscriptomics, meta-proteomics and metabolomics approaches provide an accurate understanding of the 


\section{whole microbial activities and the real physiological potential of the soil to suppress plant disease by plant- associated microbiota.}

\begin{abstract}
Abbreviations
AMF: Arbuscular mycorrhizal fungi; BCAs: Biological control agents; EMP: Earth microbiome project; GSC: Genomic standards consortium; HTS: High-throughput sequencing; ITS: Internal transcribed spacer; NCBI: National Centre for Biotechnology Information; NGS: Next-generation sequencing; OAs: Organic amendments; OTUs: Operational taxonomic units; PGPR: Plant Growth-Promoting Rhizobacteria; SOM: Soil organic matter; SRA: Sequence read archive; T-RFLP:Terminal-restriction fragment length polymorphism.
\end{abstract}

\section{Acknowledgements}

Not applicable.

\section{Authors' contributions}

The author read and approved the final manuscript.

\section{Funding}

Not applicable.

\section{Availability of data and materials}

Not applicable.

\section{Competing interests}

The author declares there are no any actual or potential competing interests including any financial, personal or other relationships with other people or organizations.

Received: 15 October 2019 Accepted: 9 March 2020

Published online: 11 September 2020

\section{References}

1. Abarenkov K, Nilsson RH, Larsson KH, Alexander IJ, Eberhardt U, Erland S, Høiland K, Kjøller R, Larsson E, Pennanen T. The UNITE database for molecular identification of fungi-recent updates and future perspectives. New Phytol. 2010;186:281-5.

2. Alabouvette C. Fusarium wilt suppressive soils: an example of diseasesuppressive soils. Australasian Plant Pathol. 1999;28:57-64.

3. Alabouvette C, Lemanceau P, Steinberg C. Recent advances in the biological control of Fusarium wilts. Pest Sci. 1993;37:365-73.

4. Aleandri MP, Chilosi G, Bruni N, Tomassini A, Vettraino AM, Vannini A. Use of nursery potting mixes amended with local Trichoderma strains with multiple complementary mechanisms to control soil-borne diseases. Crop Prot. 2015;67:269-78.

5. Angelopoulou DJ, Naska EJ, Paplomatas EJ, Tjamos SE. Biological control agents (BCAs) of $V$. dahliae wilt: influence of application rates and delivery method on plant protection, triggering of host defense mechanisms and rhizosphere populations of BCAs. Plant Pathol. 2014;63(5):1062-106.

6. Antoniou A, Tsolakidou MD, Stringlis IA, Pantelides IS. Rhizosphere microbiome recruited from a suppressive compost improves plant fitness and increases protection against vascular wilt pathogens of tomato. Front Plant Sci. 2017;8:2022. https://doi.org/10.3389/ fpls.2017.02022.

7. Araujo R, Dunlap C, Barnett S, Franco CMM. Decoding wheat endosphere-rhizosphere microbiomes in Rhizoctonia solani-infested soils challenged by streptomyces biocontrol agents. Front Plant Science. 2019;10:1038. https://doi.org/10.3389/fpls.2019.01038.

8. Araujo ASF, Miranda ARL, Oliveira MLJ, Santos VM, Nuñes LAPL, Melo WJ, Soil microbial properties after 5 years of consecutive amendment with composted tannery sludge. Environ Monit. Assess. 2015;187:1-7.

9. Avila Miranda ME, Estrella A, Peña Cabriales JJ. Colonization of the rhizosphere, rhizoplane and endorhiza of garlic (Allium sativum L.) by strains of Trichoderma harzianum and their capacity to control allium white-rot under field conditions. Soil Biol Biochem. 2006;38:1823-30.

10. Avilés $M$, Borrero $C$. Identifying characteristics of $V$. dahliae wilt suppressiveness in olive mill composts. Plant Dis. 2017;101(9):1568-77.

11. Abdallah RA, Mokni-Tlili S, Nefzi A, Jabnoun-Khiareddine H, DaamiRemadi M. Biocontrol of Fusarium wilt and growth promotion of tomato plants using endophytic bacteria isolated from Nicotiana glauca organs. Biol Control. 2016;97:80-8.

12. Bai $Y$, Wang $G$, Cheng $Y$, Shi $P$, Yang $C$, Yang $H$, Xu Z. Soil acidification in continuously cropped tobacco alters bacterial community structure and diversity via the accumulation of phenolic acids. Sci Rep. 2019;9:12499. https://doi.org/10.1038/s41598-019-48611-5.

13. Baker K, Cook RJ. Biological control of plant pathogens. San Francisco: Freeman WH Publisher; 1974.

14. Baker BJ, Tyson GW, Webb Rl, Flanagan J, Hugenholtz P, Allen EE, Banfield JF. Lineages of acidophilic archaea revealed by community genomic analysis. Science. 2006;314:1933-5. https://doi.org/10.1126/ science.1132690.

15. Bastida F, Selevsek N, Torres IF, Hernández T, García C. Soil restoration with organic amendments: linking cellular functionality and ecosystem processes. Sci Rep. 2015;5:15550.

16. Berendsen RL, Pieterse CMJ, Bakker PAHM. The rhizosphere microbiome and plant health. Trends Plant Sci. 2012;17(8):478-86.

17. Bernard E, Larkin RP, Tavantzis S, Erich MS, Alyokhin A, Sewell G, Lannan A, Gross SD. Compost, rapeseed rotation, and biocontrol agents significantly impact soil microbial communities in organic and conventional potato production systems. Appl Soil Ecol. 2012;52:29-41.

18. Berry BM, Sylvester-Bradley R, Philipp L, Hatch DJ, Cuttle SP, Rayns FW, Gosling P. Is the productivity of organic farms restricted by the supply of available nitrogen? Soil Use Manage. 2002;18:248-55.

19. Bevivino A, Paganin P, Bacci G, Florio A, Pellicer MS, Papaleo MC, Mengoni A, Ledda L, Fani R, Benedetti A, Dalmastri C. Soil bacterial community response to differences in agricultural management along with seasonal changes in a mediterranean region. PLoS ONE. 2014;9(8):e105515. https://doi.org/10.1371/journal.pone.0105515.

20. Bhadauria BP, Singh Y, Puri S, Singh PK. Ecofriendly management of Fusarium wilt of Brinjal. Ecol Environ Conserv. 2012;18:1049-52.

21. Bino RJ, Hall RD, Fiehn O, Kopka J, Saito K, Draper J, et al. Potential of metabolomics as a functional genomics tool. Trends Plant Sci. 2004;9:418-25.

22. Blaya J, Frutos C, Marhuenda J, Pascual A, Ros M. Microbiota characterization of compost using omics approaches opens new perspectives for Phytophthora root rot control. PLoS ONE. 2016;11(8):1-19. https://doi. org/10.1371/journal.pone. 0158048 .

23. Blaya J, López-Mondéjar R, Lloret E, Pascual JA, Ros M. Changes induced by Trichoderma harzianum in suppressive compost controlling Fusarium wilt. Pest Biochem Physiol. 2013;107:112-9.

24. Bonanomi G, Antignani V, Pane C, Scala F. Suppression of soilborne fungal diseases with organic amendments. J Plant Pathol. 2007;89:311-24.

25. Bonanomi G, D'Ascoli R, Scotti R, Gaglione SA, Caceres MG, Sultana S, Scelza R, Rao MA, Zoina A. Soil quality recovery and crop yield enhancement by combined application of compost and wood to vegetables grown under plastic tunnels. Agric Ecosyst Environ. 2014;192:1-7. https ://doi.org/10.1016/j.agee.2014.03.029.

26. Bonanomi G, De Filippis F, Cesarano G, La Storia A, Ercolini D, Scala F. Organic farming induces changes in soil microbiota that affect agroecosystem functions. Soil Biol Biochem. 2016;103:327-36. https://doi. org/10.1016/j.soilbio.2016.09.005.

27. Bonanomi G, Gaglione SA, Cesarano G, Sarker TC, Pascale M, Scala F, Zoina A. Frequent application of organic matter to agricultural soil increases fungistasis. Pedosphere. 2017;27:86-95. https://doi. org/10.1016/S1002-0160\%5b15\%5d600.

28. Borrero C, Castillo S, Segarra G, Trillas MI, Castaño R, Avilés M. Capacity of composts made from agriculture industry residues to suppress different plant diseases. Acta Hortic. 2013;1013:459-63.

29. Bouizgarne B. Bacteria for plant growth promotion and disease management. In: Maheshwari DK, editor. Bacteria in agrobiology: disease management. Berlin: Springer; 2013. p. 15-47.

30. Branton D, Deamer DW, Marziali A, Bayley H, Benner SA, Butler T, et al. The potential and challenges of nanopore sequencing. Nat Biotechnol. 2008;26:1146-53. https://doi.org/10.1038/nbt.1495. 
31. Breidenbach B, Blaser MB, Klose M, Conrad R. Crop rotation of flooded rice with upland maize impacts the resident and active methanogenic microbial community. Environ Microbiol. 2016;18:2868-85.

32. Bronick C, Lal R. Soil structure and management: a review. Geoderma. 2005;124:3-22. https://doi.org/10.1016/j.geoderma.2004.03.005.

33. Bulluck LR, Brosius M, Evanylo GK, Ristaino JB. Organic and synthetic fertility amendments influence soil microbial, physical and chemical properties on organic and conventional farms. Appl Soil Ecol. 2002;19:147-60. https://doi.org/10.1016/S0929-1393(01)00187-1.

34. Cao Y, Fanning S, Proos S, Jordan K, Srikumar S. A review on the applications of next generation sequencing technologies as applied to foodrelated microbiome studies. Front Microbiol. 2017;8:1829. https://doi. org/10.3389/fmicb.2017.01829.

35. Cao Y, Zhang Z, Ling N, Yuan Y, Zheng X, Shen B, Shen Q. Bacillus subtilis SQR 9 can control Fusarium wilt in cucumber by colonizing plant roots. Biol Fertil Soils. 2011:47:495-506.

36. Caporaso JG, Kuczynski J, Stombaugh J, Bittinger K, Bushman FD, Costello EK, Fierer N, Peña AG, et al. QIIME allows analysis of highthroughput community sequencing data. Nat Methods. 2010;7:335.

37. Caporaso JG, Lauber CL, Walters WA, Berg-Lyons D, Lozupone CA, Turnbaugh PJ, Fierer N, Knight R. Global patterns of 16 S rRNA diversity at a depth of millions of sequences per sample. Proc Natl Acad Sci USA. 2011;108:4516-22.

38. Caravaca F, Hernández T, García C, Roldán A. Improvement of rhizosphere aggregate stability of afforested semiarid plant species subjected to mycorrhizal inoculation and compost addition. Geoderma. 2002;108:133-44

39. Castãno R, Borrero C, Avilés M. Organic matter fractions by SP-MAS 13C NMR and microbial communities involved in the suppression of fusarium wilt in organic growth media. Biol Control. 2011;58(3):286-93.

40. Castãno R, Borrero C, Trillas Ml, Avilés M. Selection of biological control agents against tomato Fusarium wilt and evaluation in greenhouse conditions of two selected agents in three growing media. Biocontrol. 2013;58:105-16.

41. Celik I, Ortas I, Kilic S. Effects of compost, mycorrhiza, manure and fertilizer on some physical properties of a Chromoxerert soil. Soil Till Res. 2004;78:59-67.

42. Cesarano G, De Filippis F, La Storia A, Scala F, Bonanomi G. Organic amendment type and application frequency affect crop yields, soil fertility and microbiome composition. Appl Soil Ecol. 2017;120:254-64.

43. Cha JY, Han S, Hong HJ, Cho H, Kim D, Kwon Y. Microbial and biochemical basis of a Fusarium oxysporum f sp melonis wilt-suppressive soil. ISME J. 2016;10:119-29.

44. Chen W, Hoitink HAJ, Schmitthenner A. Factors affecting suppression of pythium damping-off in container media amended with composts. Phytopathology. 1987;77(5):755-60.

45. Chilosi G, Aleandri MP, Bruni N, Tomassini A, Torresi V, Muganu M, Paolocci M, Vettraino A, Vannini A. Assessment of suitability and suppressiveness of on-farm green compost as a substitute of peat in the production of lavender plants. Biocontrol Sci Technol. 2017;27(4):539-55.

46. Claudia C, McLean M, Berjak P. In vitro studies on the potential for biological control of Aspergillus flavus and Fusarium moniliforme by Trichoderma spp. Mycopathologia. 1997;137:115-24.

47. Cole JR, Wang Q, Fish JA, Chai B, Mcgarrell DM, Sun Y, Brown CT, Porrasalfaro A, Kuske CR, Tiedje JM. Ribosomal database project: data and tools for high-throughput rRNA analysis. Nucleic Acids Res. 2014:42:D633.

48. Cordier C, Gianinazzi S, Gianinazzi-Pearson V. Colonisation patterns of root tissues by Phytophthora nicotianae var parasitica related to reduced disease in mycorrhizal tomato. Plant Soil. 1996;185(2):223-32.

49. Cotxarrera L, Trillas MI, Steinberg C, Alabouvette C. Use of sewage sludge compost and Trichoderma asperellum isolates to suppress Fusarium oxysporum f sp melonis wilt of tomato. Soil Biol Biochem. 2002;34:467-76

50. Cretoiu MS, Korthals GW, Visser JHM, Van Elsas JD. Chitin amendment increases soil suppressiveness toward plant pathogens and modulates the actinobacterial and oxalobacteraceal communities in an experimental agricultural field. Appl Environ Microbiol. 2013;79:5291-301.
51. Croteau GA, Zibilske LM. Influence of papermill processing residuals on saprophytic growth and disease caused by Rhizoctonia solani. Appl Soil Ecol. 1998:10:103-15.

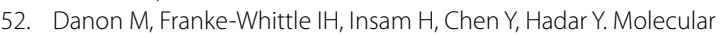
analysis of bacterial community succession during prolonged compost curing. FEMS Microbiol Ecol. 2008;65(1):133-44. https://doi.org/10.111 1/j.1574-6941.2008.00506.x.

53. Da Mota FF, Gomes EA, Seldin L. Auxin production and detection of the gene coding for the auxin efflux carrier (AEC) protein in Paenibacillus polymyxa. J Microbiol. 2008;46(3):257-64.

54. De Corato U. Disease-suppressive compost enhances natural soil suppressiveness against soil-borne plant pathogens: a critical review. Rhizosphere. 2020;13:100192. https://doi.org/10.1016/j.rhisp h.2020.100192.

55. De Corato U, Patruno L, Avella N, Lacolla G, Cucci G. Composts from green sources show an increased suppressiveness to soilborne plant pathogenic fungi: relationships between physicochemical properties, disease suppression, and the microbiome. Crop Prot. 2019;124:104870. https://doi.org/10.1016/j.cropro.2019.104870.

56. De Corato U, Salimbeni R, De Pretis A, Patruno L, Avella N, Lacolla G, Cucci G. Microbiota from 'next-generation green compost' improves suppressiveness of composted Municipal-Solid-Waste to soil-borne plant pathogens. Biol Control. 2018;124:1-17. https://doi.org/10.1016/j. biocontrol.2018.05.020.

57. De Corato U, Viola E, Arcieri G, Valerio V, Zimbardi F. Use of composted agro-energy co-products and agricultural residues against soil-borne pathogens in horticultural soil-less systems. Sci Hortic. 2016:210:16679. https://doi.org/10.1016/j.scienta.2016.07.027.

58. Deepa C, Dastager SG, Pandey A. Plant growth-promoting activity in newly isolated Bacillus thioparus (NII-0902) from Western ghat forest, India. World J Microbiol. Biotechnol. 2010;26(12):2277-83.

59. de la Cruz JMR, Lora JM, Hidalgo-Galiego A, Dominguez F, PintorToro JA, Llobell A, Benitez T. Carbon source control on $\beta$-glucanases, chitobiase and chitinase from Trichoderma harzianum. Ann Microbiol. 1993;159:316-22.

60. De Meyer G, Bigrimana G, Elad Y, Hofte M. Induced systemic resistance in T. harzianum T396 biocontrol of Botrytis cinerea. Eur J Plant Pathol. 1998:104:279-86

61. Deng X, Zhang N, Shen Z, Zhu C, Li R, Falcao Salles J, Shen Q. Rhizosphere bacteria assembly derived from fumigation and organic amendment triggers the direct and indirect suppression of tomato bacterial wilt disease. Appl Soil Ecol. 2019. https://doi.org/10.1016/j.apsoi I.2019.103364 (in press)

62. Desantis TZ, Hugenholtz P, Larsen N, Rojas M, Brodie EL, Keller K, Huber T, Dalevi D, Hu P, Andersen GL. Greengenes, a chimera-checked 16S rRNA gene database and workbench compatible with ARB. Appl Environ Microbiol. 2006;72:5069-72.

63. Deurenberg RH, Bathoorn E, Chlebowicz MA, Couto N, Ferdous M, Garcia-Cobos S, Kooistra-Smid AM, Raangs EC, Rosema S, Veloo AC, Zhou K, Friedrich AW, Rossen JW. Application of next generation sequencing in clinical microbiology and infection prevention. J Biotechnol. 2017;243:16-24. https://doi.org/10.1016/j.jbiotec.2016.12.022.

64. De Weger L, Van Boxtel R, Van der Burg B, Gruters R, Geels F, Schippers B, Lugtenberg B. Siderophores and outer membrane proteins of antagonistic, plant-growth-stimulating, root-colonizing Pseudomonas spp. J Bacteriol. 1986;165(2):585-94.

65. Dignam BEA, O'Callaghan M, Condron LM, Raaijmakers JM, Kowalchuk GA, Wakelin SA. Impacts of long-term plant residue management on soil organic matter quality, Pseudomonas community structure and disease suppressiveness. Soil Biol Biochem. 2019;135:396-406. https:// doi.org/10.1016/j.soilbio.2019.05.020.

66. Di Lenola M, Grenni P, Proença D, Morais P, Caracciolo A. Comparison of two molecular methods to assess soil microbial diversity. In: Lukac M, Grenni P, Gamboni M, editors. Soil biological communities and ecosystem resilience, sustainability in plant and crop protection series. Switzerland: Springer; 2017. p. 25-42.

67. Domínguez P, Miranda L, Soria C, de los Santos B, Chamorro M, Romero F, Daugovish O, Lopez-Aranda JM, Medina JJ. Soil biosolarization for sustainable strawberry production. Agron Sustain Dev. 2014;34:821-9.

68. Duong TTT, Verma SL, Penfold C, Marschner P. Nutrient release from composts into the surrounding soil. Geoderma. 2013;195(196):42-7. 
69. Edgar RC. Search and clustering orders of magnitude faster than BLAST. Bioinformatics. 2010;26:2460-1.

70. Edgar RC. UPARSE: highly accurate OTU sequences from microbial amplicon reads. Nat Methods. 2013;10:996-8.

71. Edgar RC, Haas BJ, Clemente JC, Quince C, Knight R. UCHIME improves sensitivity and speed of chimera detection. Bioinformatics. 2011;27:2194.

72. El-Masry M, Khalil A, Hassouna M, Ibrahim H. In situ and in vitro suppressive effect of agricultural composts and their water extracts on some phytopathogens. World J Microbiol Biotechnol. 2002;18(6):551-8.

73. Eren AM, Maignien L, Sul WJ, Murphy LG, Grim SL, Morrison HG, Sogin ML. Oligotyping: differentiating between closely related microbial taxa using $16 \mathrm{~S}$ rRNA gene data. Methods Ecol Evol. 2013:4:1111-9. https:// doi.org/10.1111/2041-210X.12114

74. Erlich Y, Mitra PP, delaBastide M, McCombie WR, Hannon GL. Alta-Cyclic: a self-optimizing base caller for next generation sequencing. Nat Methods. 2008;5:679-82.

75. Evanylo G, Sherony C, Spargo J, Starner D, Brosius M, Haering K. Soil and water environmental effects of fertilizer- manure-, and compost-based fertility practices in an organic vegetable cropping system. Agr Ecosyst Environ. 2008;127:50-8.

76. Fadrosh DW, Bing M, Gajer P, Sengamalay N, Ott S, Brotman RM, Ravel J. An improved dual-indexing approach for multiplexed 16S rRNA gene sequencing on the Illumina MiSeq platform. Microbiome. 2014;2:1-7.

77. Forbes JD, Knox NC, Ronholm J, Pagotto F, Reimer A. Metagenomics: the next culture-independent game changer. Front. Microbiol. 2017:8:1069. https://doi.org/10.3389/fmicb.2017.01069.

78. García-Gil JC, Plaza C, Soler-Rovira P, Polo A. Long-term effects of municipal solid waste compost application on soil enzyme activities and microbial biomass. Soil Biol Biochem. 2000;32:1907-13.

79. Gardes M, Bruns TD. ITS primers with enhanced specificity for basidiomycetes - application to the identification of mycorrhizae and rusts. Mol Ecol. 1993;2:113-8. https://doi.org/10.1111/j.1365-294X.1993.tb000 05.X.

80. Ghini R, Patricio FRA, Bettiol W, Almeida IMG, Maia ADHN. Effect of sewage sludge on suppressiveness to soil-borne plant pathogens. Soil Biol Biochem. 2007:39:2797-805

81. Gil MV, Carballo MT, Calvo LF. Fertilization of maize with compost from cattle manure supplemented with additional mineral nutrients. Waste Manage. 2008;28:1432-40.

82. Griffiths BS, Philippot L. Insights into the resistance and resilience of the soil microbial community. FEMS Microbiol Rev. 2013;37:112-29. https:// doi.org/10.1111/j.1574-6976.2012.00343.x.

83. Haas D, Défago G. Biological control of soil-borne pathogens by fluorescent pseudomonads. Nat Rev Microbiol. 2005;3:307-19.

84. Hadar Y, Papadopoulou KK. Suppressive composts: microbial ecology links between abiotic environments and healthy plants. Annu Rev Phytopathol. 2012;50:133-53.

85. Haggag WM, Saber MSM. Evaluation of three compost as multi-strain carriers for biofertilizer and biocontrol agents against Fusarium wilt disease of some legume plants. Arab J Biotechnol. 2000;3:133-44.

86. Hannan MA, Hasan MM, Hossain I, Rahman SME, Ismail AM, Oh DH. Integrated management of foot rot of lentil using biocontrol agents under field condition. J Microbiol Biotechnol. 2012;22:883-8.

87. Hardy GE, Sivasithamparam K. Suppression of Phytophthora nicotianae root rot by a composted eucalyptus bark mix. Aust J Bot. 1991;39:153-9.

88. Harman GE, Hayes CK, Lorito M, Broadway RM, Di Pietro A, Peterbauer C, Tronsmo A. Chitinolytic enzymes of Trichoderma harzianum: purification of chitobiosidase and endochitinase. Phytopathology. 1993;83:313-8.

89. Hemmat A, Aghilinategh N, Rezainejad Y, Sadeghi M. Long-term impacts of municipal solid waste compost, sewage sludge and farmyard manure application on organic carbon, bulk density and consistency limits of a calcareous soil in central Iran. Soil Till Res. 2010:108:43-50.

90. Himmelstein JC, Maul JE, Everts KL. Impact of five cover crop green manures and actinovate on fusarium wilt of watermelon. Plant Dis. 2014;98:965-72. https://doi.org/10.1094/PDIS-06-13-0585-RE.

91. Hoitink HAJ, Boehm MJ. Biocontrol within the contest of soil microbial communities: a substrate-dependent phenomenon. Annu Rev Phytopathol. 1999;37:427-46.
92. Hoitink HAJ, Boehm MJ, Hadar Y. Mechanism of suppression of soil borne plant pathogen in compost-amended substrates. In: Hoitink HAJ, Keener HM, editors. Science and engineering of composting: design, environmental, microbiological and utilization aspects. Worthington: Renaissance Publication; 1993. p. 601-21.

93. Hoitink HAJ, Fahy PC. Basis for the control of soilborne plant pathogens with composts. Annu Rev Phytopathol. 1986;24:93-114.

94. Hoitink HAJ, Krause MS, Han DY. Spectrum and mechanisms of plant disease control with composts. In: Stoffella PJ, Kahn BA, editors. Compost Utilization in Horticultural Cropping Systems. Boca Raton: Lewis Publishers; 2001. p. 263-74.

95. Hoitink HAJ, Madden LV, Dorrance AE. Systemic resistance induced by Trichoderma spp.: interaction between the host, the pathogen, the biocontrol agent, and the soil organic matter quality. Phytopathology. 2006;96(2):186-9.

96. Hoitink HAJ, Stone AG, Han DY. Suppression of plant diseases by composts. HortScience. 1997;32:184-7.

97. Huang Y, Sun L, Zhao J, Huang R, Li R, Shen Q. Utilization of different waste proteins to create a novel PGPR-containing bio-organic fertilizer. Scientific Reports. 2015;5:7766. https://doi.org/10.1038/srep07766.

98. Huang X, Zhang N, Yong X, Yang X, Shen Q. Biocontrol of Rhizoctonia solani damping-off disease in cucumber with Bacillus pumilus SQR-N43. Microbiol Res. 2012;167:135-43.

99. Hussain I, Alam SS, Khan I, Shah B, Naeem A, Khan N, Ullah W, lqbal B, Adnan M, Junaid K, Shah SRA, Ahmed N, lqbal M. Study on the biological control of fusarium wilt of tomato. J Entomol Zool Studies. 2016:4(2):525-8.

100. Hwang BK, Ahn SJ, Moon SS. Production, purification, and antifungal activity of the antibiotic nucleoside, tubercidin, produced by Streptomyces violaceus-niger. Can J Bot. 1994;72:480-5.

101. Insam H, Riddech N, Klammer S, editors. Microbiology of composting. Heidelberg: Springer; 2002. p. 435-44.

102. Islam MdR, Jeong YT, Lee YS, Song CH. Isolation and identification of antifungal compounds from Bacillus subtilis C9 inhibiting the growth of plant pathogenic fungi. Mycobiology. 2012;40(1):59-66.

103. Jagadeesan B, Gerner-Smid P, Allard MW, Leuillet S, Winkler A, et al. The use of next generation sequencing for improving food safety: translation into practice. Food Microbiol. 2019;79:96-115. https://doi. org/10.1016/j.fm.2018.11.005

104. Jaiswal AK, Elad Y, Cytryn E, Graber ER, Frenkel O. Activating biochar by manipulating the bacterial and fungal microbiome through preconditioning. New Phytol. 2018. https://doi.org/10.1111/nph.15042.

105. Jambhulkar PP, Sharma M, Lakshman D, Sharma P. Natural mechanisms of soil suppressiveness against diseases caused by Fusarium, Rhizoctonia, Pythium, and Phytophthora. In: Meghvansi MK, Varma A, editors. Organic amendments and soil suppressiveness in plant disease management. Springer: New York; 2015. p. 95-124.

106. Janssen PH. Identifying the dominant soil bacterial taxa in libraries of 16S rRNA and 16S rRNA genes. Appl Environ Microbiol. 2006;72:171928. https://doi.org/10.1128/AEM.72.3.1719-1728.2006.

107. Jayaraj J, Parthasarathi P, Adhakrishnan NV. Characterization of a Pseudomonas fluorescens strain from tomato rhizosphere and its use for integrated management of tomato damping-off. Biocontrol. 2007:52:683-702.

108. Jiang YJ, Liang YT, Li CM, Wang F, Sui YY, Suvannang N, Zhou JZ, Sun B. Crop rotations alter bacterial and fungal diversity in paddy soils across East Asia. Soil Biol Biochem. 2016:95:250-61.

109. Johnson JS, Spakowicz DJ, Hong BY, Petersen LM, Demkowicz P, Chen L, Leopold SR, Hanson BM, et al. Evaluation of $16 \mathrm{~S}$ rRNA gene sequencing for species and strain-level microbiome analysis. Nat Commun. 2019;10(1):5029. https://doi.org/10.1038/s41467-019-13036-1.

110. Jones DL, Rousk J, Edwards-Jones G, DeLuca TH, Murphy DV. Biochar mediated changes in soil quality and plant growth in a three year field trial. Soil BiolBiochem. 2012:45:113-24. https://doi.org/10.1016/j.soilb io.2011.10.012.

111. Joshi D, Hooda KS, Bhatt JC. Integration of soil solarization with biofumigation and Trichoderma spp for management of damping-off in tomato (Lycopersicon esculentum) in the mid altitude region of northwestern Himalayas. Indian J Agric Sci. 2009;79:754-7.

112. Kanaan H, Hadar Y, Medina S, Krasnovsky A, Mordechai-Lebiush S, Tsror L, Katan J, Raviv M. Effect of compost properties on progress rate of 
Verticillium dahliae attack on eggplant (Solanum melongena L.). Compost Sci Utiliz. 2017. https://doi.org/10.1080/1065657X.2017.1366375.

113. Kariuki GM, Muriuki LK, Kibiro EM. The impact of suppressive soils on plant pathogens and agricultural productivity. In: Meghvansi MK, Varma A, editors. Organic amendments and soil suppressiveness in plant disease management. Springer: New York; 2015. p. 3-24. https://doi. org/10.1007/978-3-319-23075-7

114. Kefalogianni I, Gkizi D, Pappa E, Dulaj L, Tjamos SE, Chatzipavlidis I. Combined use of biocontrol agents and zeolite as a management strategy against $F$. oxysporum $\mathrm{f}$. sp. melonis and $V$. dahliae wilt. Biocontrol. 2017;62(2):139-50.

115. Kibblewhite MG, Ritz K, Swift MJ. Soil health in agricultural systems. Trans R Soc Biol Sci. 2008;363:685-701.

116. Kilany M, Ibrahim EH, AlAmry S, Al Roman S, Siddiqui S. Microbial suppressiveness of Pythium damping-Off diseases. In: Meghvansi MK, Varma A, editors. Organic amendments and soil suppressiveness in plant disease management. Springer: New York; 2015. p. 187-206. https ://doi.org/10.1007/978-3-319-23075-7.

117. Kim YC, Leveau J, McSpadden Gardener BB, Pierson EA, Pierson LS, Ryu $\mathrm{CM}$. The multifactorial basis for plant health promotion by plant-associated bacteria. Appl Environ Microbiol. 2011;77:1548-55.

118. Klammer S, Knapp B, Insam H, Dell'Abate MT, Ros M. Bacterial community patterns and thermal analyses of composts of various origins. Waste Manag Res. 2008;26(2):173-87.

119. Kloepper JW, Rodriguez-Ubana R, Zehnder GW, Murphy JF, Sikora E, Fernandez C. Plant root-bacterial interactions in biological control of soilborne diseases and potential extension to systemic and foliar diseases. Aust Plant Pathol. 1999;28:21-6.

120. Krause SM, Madden LV, Hoitink HAJ. Effect of potting mix microbial carrying capacity on biological control of Rhizoctonia solani damping off of radish and $R$. solani crown and root rot of poinsettia. Phytopathology. 2001;91:1116-23.

121. Kullnig-Gradinger CM, Szakacs G, Kubicek CP. Phylogeny and evolution of the fungal genus Trichoderma: a multigene approach. Mycol Res. 2002;106:757-67.

122. Kwok OCH, Fahy PC, Hoitink HAJ, Kuter GA. Interactions between bacteria and Trichoderma hamatum in suppression of Rhizoctonia solani damping-off in bark compost media. Phytopathology. 1987;77(8):1206-12.

123. Lang J, Hu J, Ran W, Xu Y, Shen Q. Control of cotton Verticillium wilt and fungal diversity of rhizosphere soils by bio-organic fertilizer. Biol Fertil Soils. 2012:48:191-203.

124. Larkin RP, Fravel DR. Efficacy of various fungal and bacterial biocontrol organisms for control of fusarium wilt of tomato. Plant Dis. 1998;82(9):1022-8.

125. Latha P, Anand T, Prakasam V, Jonathan EI, Paramathma M, Samiyappan R. Combining Pseudomonas, Bacillus and Trichoderma strains with organic amendments and micronutrient to enhance suppression of collar and root rot disease in physic nut. Appl Soil Ecol. 2011:49:215-23.

126. Lazarovits $\mathrm{G}$. Managing soilborne disease of potatoes using ecologically based approaches. Am J Potato Res. 2010;87:401-11.

127. Lazarovits G, Abbasi PA, Conn KL, Hill JE, Hemmingsen JE. Fish emulsion and liquid swine manure: model systems for development of organic amendments as fertilizers with disease suppressive properties. In: Bettiol W, Morandi M, editors. Biocontrole de Doenças de Plantas: Uso e Perspectivas. Jaguariúna-SP: Embrapa Meio Ambiente; 2009. p. 49-67.

128. Lazarovits G, Conn KL, Abbasi PA, Tenuta M. Understanding the mode of action of organic soil amendments provides the way for improved management of soilborne plant pathogens. Acta Hortic. 2005:698:215-24

129. Lehmann J, Rillig MC, Thies J, Masiello CA, Hockaday WC, Crowley D. Biochar effects on soil biota-a review. Soil Biol Biochem. 2011;43:1812-36.

130. Lemanceau P, Alabouvette C. Suppression of fusarium wilts by fluorescent pseudomonads: mechanisms and applications. Biocontrol Sci Technol. 2008;3:219-34. https://doi.org/10.1080/09583159309355278.

131. Lemos $L N$, et al. Bioinformatics for microbiome research: concepts, strategies, and advances. The Brazilian Microbiome. Cham: Springer; 2017. p. 111-23.
132. Leonard SR, Mammel MK, Lacher DW, Elkins CA. Strain-level discrimination of shiga toxin-producing Escherichia coli in spinach using metagenomic sequencing. PLoS ONE. 2016;11(12):e0167870. https:// doi.org/10.1371/journal.pone.0167870.

133. Li H, Cai X, Gong J, Xu T, Ding G, Li J. Long-term organic farming manipulated rhizospheric microbiome and bacillus antagonism against pepper blight (Phytophthora capsici). Front Microbiol. 2019;10:342. https ://doi.org/10.3389/fmicb.2019.00342.

134. Li X, de Boer W, Zhang Y, Ding C, Zhang T, Wang X. Suppression of soil-borne Fusarium pathogens of peanut by intercropping with the medicinal herb Atractylodes lancea. Soil Biol Biochem. 2018;116:120-30. https://doi.org/10.1016/j.soilbio.2017.09.029.

135. Li XG, Ding CF, Zhang TL, Wang XX. Fungal pathogen accumulation at the expense of plant-beneficial fungi as a consequence of consecutive peanut monoculturing. Soil Biol Biochem. 2014;72:11-8.

136. Liu L, Kloepper JW, Tuzun S. Induction of systemic resistance in cucumber against Fusarium wilting plant growth-promoting rhizobacteria. Phytopathology. 1995;85:695-8.

137. Liu M, Wang X, Sun L, Zhao J, Ling Z, Li Z, Zhao X. High-efficiency cultivation model of cherry tomato and rice rotation in south of China. Hum Agric Sci. 2018;26:21-3.

138. Liu H, Xiong W, Zhang R, Hang X, Wang D, Li R, Shen Q. Continuous application of different organic additives can suppress tomato disease by inducing the healthy rhizospheric microbiota through alterations to the bulk soil microflora. Plant Soil. 2018;423:229-40. https://doi. org/10.1007/s11104-017-3504-6.

139. Loman NJ, Pallen MJ. Twenty years of bacterial genome sequencing. Nat Rev Microbiol. 2015;13(12):787-94. https://doi.org/10.1038/nrmic ro3565.

140. Lopes AR, Manaia CM, Nuñes OC. Bacterial community variations in an alfalfa-rice rotation system revealed by $16 \mathrm{~S}$ rRNA gene 454-pyrosequencing. FEMS Microbiol Ecol. 2014;87:650-63.

141. Lozupone C, Hamady M, Knight R. UniFrac - an online tool for comparing microbial community diversity in a phylogenetic context. BMC Bioinformatics. 2006:7:371.

142. Lu L, Yin S, Liu X, Zhang W, Gu T, Shen Q, Qiu H. Fungal networks in yield-invigorating and-debilitating soils induced by prolonged potato monoculture. Soil Biol Biochem. 2013;65:186-94.

143. Luo C, Tsementzi D, Kyrpides N, Read T, Konstantinidis KT. Direct comparisons of illumina vs roche 454 sequencing technologies on the same microbial community DNA sample. PLoS ONE. 2012;7(2):e30087. https://doi.org/10.1371/journal.pone.0030087.

144. Mago T, Salzberg SL. FLASH: fast length adjustment of short reads to improve genome assemblies. Bioinformatics. 2011;27:2957-63.

145. Mahatma MK, Mahatma L. Soil suppressive microorganisms and their impact on fungal wilt pathogens. In: Meghvansi MK, Varma A, editors. Organic amendments and soil suppressiveness in plant disease management. Springer: New York; 2015. p. 249-75. https://doi. org/10.1007/978-3-319-23075-7.

146. Manici LM, Caputo F. Soil fungal communities as indicators for replanting new peach orchards in intensively cultivated areas. Eur J Agronomy. 2010;33:188-96.

147. Manici LM, Caputo F, Babini V. Effect of green manure on Pythium spp. population and microbial communities in intensive cropping systems. Plant Soil. 2004;263:133-42.

148. Margulies M, Egholm M, Altman WE, Attiya S, Bader JS, et al. Genome sequencing in microfabricated high-density picolitre reactors. Nature. 2005:437:376-80.

149. Martin St. CCG. 2015 Enhancing soil suppressiveness using compost. In: Meghvansi MK, Varma A, eds. Organic amendments and soil suppressiveness in plant disease management 2015, pp. 25-50. Springer Series Soil biology, Vol. 46, ISSN 1613-3382, ISSN 2196-4831 (electronic), ISBN 978-3-319-23074-0, ISBN 978-3-319-23075-7 (eBook). Springer International Publishing Switzerland. https://doi.org/10.1007/978-3-319-23075 $-7$.

150. Martínez-Blanco J, Lazcano C, Christensen TH, Muñoz P, Rieradevall J, Møller J, Antón A, Boldrin A. Compost benefits for agriculture evaluated by life cycle assessment. A review. Agron Sustain Dev. 2013;33:721-32.

151. Maurhfiofer M, Flace C, Meuwly P, Defagu G. Induction of systemic resistance in cucumber by Pseudomonas syringae pv. syringae. Physiol Mol Plant Pathol. 1994;38:223-35. 
152. McGee CF, Doyle O, Gaffney MT. Bio-prospecting for potential microbial biocontrol agents from composted waste materials. Acta Hortic. 2016;1112:335-42.

153. McQuilken MP, Whipps JM, Lynch JM. Effects of water extract of a composted manure straw mixture on the plant pathogen Botrytis cinerea. World J Microbiol Biotechnol. 1994;10:20-6.

154. Mehta C, Palni U, Franke-Whittle I, Sharma A. Compost: its role, mechanism and impact on reducing soil-borne plant diseases. Waste Manag. 2014;34(3):607-22.

155. Melero S, Porras JCR, Herencia JF, Madejon E. Chemical and biochemical properties in a silty loam soil under conventional and organic management. Soil Tillage Res. 2006;90:162-70. https://doi.org/10.1016/j.still 2005.08.016.

156. Melero-Vara JM, López-Herrera CJ, Prados-Ligero AM, Vela-Delgado MD, Navas-Becerra JA, Basallote-Ureba MJ. Effects of soil amendment with poultry manure on carnation Fusarium wilt in greenhouses in southwest Spain. Crop Prot. 2011;30:970-6.

157. Mendes R, Kruijt M, de Bruiin I, Dekkers E, van der Voort M, Schneider JH, Piceno YM, De Santis TZ, Andersen GL, Bakker PA, Raaijmakers JM. Deciphering the rhizosphere microbiome for disease-suppressive bacteria. Science. 2011;332:1097-100.

158. Meng T, Wang $Q$, Abbasi $P, M a Y$. Deciphering differences in the chemical and microbial characteristics of healthy and Fusarium wiltinfected watermelon rhizosphere soils. Appl Microbiol Biotechnol. 2019;103:1497-509. https://doi.org/10.1007/s00253-018-9564-6.

159. Mercado-Blanco J, Abrantes I, Barra Caracciolo A, Bevivino A, Ciancio A, Grenni P, Hrynkiewicz K, Kredics L, Proença DN. Belowground microbiota and the health of tree crops. Front Microbiol. 2018;9:1006. https:// doi.org/10.3389/fmicb.2018.01006.

160. Mercado-Blanco J, Rodriguez-Jurado D, Hervàs A, Jimènez-Diaz JM. Suppression of Verticillium dahliae wilt in olive planting stocks by root associated fluorescent Pseudomonas spp. Biol Control. 2004;30:474-86.

161. Meyer JR, Linderman R. Selective influence on populations of rhizosphere or rhizoplane bacteria and actinomycetes by mycorrhizas formed by Glomus fasciculatum. Soil Biol Biochem. 1986;18(2):191-6.

162. Morra L, Pagano L, lovieno P, Baldantoni D, Alfani A. Soil and vegetable crop response to addition of different levels of municipal waste compost under Mediterranean greenhouse conditions. Agron Sustain Dev. 2010;30:701-9.

163. Murugan R, Kumar S. Influence of long-term fertilisation and crop rotation on changes in fungal and bacterial residues in a tropical rice-field soil. Biol Fertil Soils. 2013;49:847-56.

164. Nair A, Ngouajio M. Soil microbial biomass, functional microbial diversity, and nematode community structure as affected by cover crops and compost in an organic vegetable production system. Appl Soil Ecol. 2012;58:45-55.

165. Nannipieri P, Penton CR, Purahong W, Schloter M, et al. Recommendations for soil microbiome analyses. Biol Fertil Soils. 2019;55:765-6.

166. Nayyar A, Hamel C, Lafond G, Gossen BD, Hanson K, Germida J. Soil microbial quality associated with yield reduction in continuouspea. Appl Soil Ecol. 2009;43:115-21. https://doi.org/10.1016/j.apsoi 1.2009.06.008.

167. Neeraj Singh K. Organic amendments to soil inoculated arbuscular mycorrhizal fungi and Pseudomonas fluorescens treatments reduce the development of root-rot disease and enhance the yield of Phaseolus vulgaris L. Eur J Soil Biol. 2011;47:288-95.

168. Ng EL, Bandow C, Proença DN, Santos S, Guilherme R, Morais PV, et al. Does altered rainfall regime change pesticide effects in soil? A terrestrial model ecosystem study from Mediterranean Portugal on the effects of pyrimethanil to soil microbial communities under extremes in rainfall. Appl Soil Ecol. 2014;84:245-53. https://doi.org/10.1016/j.apsoi 1.2014.08.006.

169. Nguyen NV, Kim YY, Oh KT, Jung WJ, Park RD. Antifungal activity of chitinases from Trichoderma aureoviride DY-59 and Rhizopus microsporus VS-9. Curr Microbiol. 2008;56:28-32.

170. Noble R, Coventry E. Suppression of soil-borne plant diseases with composts: a review. Biocontrol Sci Technol. 2005;15:3-20. https://doi. org/10.1080/09583150400015904.

171. O'Donnell AG, Colvan SR, Malosso E. Twenty years of molecular analysis of bacterial communities in soils and what have we learned about function? In: Bardgett RD, Usher MB, Hopkins DW, editors. Biological diversity and function in soils. New York: Cambridge University Press; 2005. p. 44-73.

172. Ou Y, Penton CR, Geisen S, Shen Z, Sun Y, Lv N, Wang B, Ruan Y, Xiong W, $L i R$, Shen $Q$. Deciphering underlying drivers of disease suppressiveness against pathogenic Fusarium oxysporum. Front Microbiol. 2019;10:2535. https://doi.org/10.3389/fmicb.2019.02535.

173. Palaniyandi SA, Yang SH, Zhang L, Suh JW. Effects of actinobacteria on plant disease suppression and growth promotion. Appl Microbiol Biotechnol. 2013;97:9621-36.

174. Pane C, Celano G, Piccolo A, Villecco D, Spaccini R, Palese AM, Zaccardelli M. Effects of on-farm composted tomato residues on soil biological activity and yields in a tomato cropping system. Chem Biol Technol Agric. 2015. https://doi.org/10.1186/s40538-014-0026-9.

175. Pane C, Piccolo A, Spaccini R, Celano G, Villecco D, Zaccardelli M. Agricultural waste-based composts exhibiting suppressivity to diseases caused by the phytopathogenic soil-borne fungi Rhizoctonia solani and Sclerotinia minor. Appl Soil Ecol. 2013;65:43-51.

176. Pérez-Piqueres A, Edel-Hermann W, Alabouvette C, Steinberg C. Response of soil microbial communities to compost amendments. Soil Biol Biochem. 2006;38:460-70.

177. Pharand B, Carisse O, Benhamou N. Cytological aspects of compostmediated induced resistance against fusarium crown and root rot in tomato. Phytopathology. 2002;92(4):424-38.

178. Porras-Alfaro A, Liu K-L, Kuske CR, Xie G. From genus to phylum: largesubunit and internal transcribed spacer rRNA operon regions show similar classification accuracies influenced by database composition. Appl Environ Microbiol. 2014;80:829-40. https://doi.org/10.1128/AEM.02894 $-13$.

179. Postma J, Schilder MT, Bloem J, van Leeumen-Haagsma WK. Soil suppressiveness and functional diversity of the soil microflora in organic farming systems. Soil Biol Biochem. 2008:40:2394-406.

180. Proença DN, Francisco R, Kublik S, Schöler A, Vestergaard G, Schloter $M$, et al. The microbiome of endophytic, wood colonizing bacteria from pine trees as affected by pine wilt disease. Sci. Rep. 2017;7:4205. https://doi.org/10.1038/s41598-017-04141-6.

181. Pugliese M, Liu BP, Gullino ML, Garibaldi A. Selection of antagonists from compost to control soil-borne pathogens. J Plant Dis Prot. 2008;115:220-8.

182. Quince C, Lanzen A, Curtis TP, Davenport RJ, Hall N, et al. Accurate determination of microbial diversity from 454-pyrosequencing data. Nat Methods. 2009;6:639-41.

183. Raaijmakers JM, Leeman M, Van Oorschot MMP, Van der Sluis I, Schippers B, Bakker PAHM. Dose-response relationships in biological control of Fusarium wilt of radish by Pseudomonas spp. Phytopathology. 1995;85:1075-81.

184. Ruano-Rosa D, Mercado-Blanco J. Combining biocontrol agents and organics amendments to manage soil-borne phytopathogens. In: Meghvansi MK, Varma A (Eds.) Organic amendments and soil suppressiveness in plant disease management. 2015, pp. 457-478. ISSN 1613-3382, ISSN 2196-4831 (electronic), ISBN 978-3-319-23074-0, ISBN 978-3-319-23075-7 (eBook). Springer International Publishing Switzerland. http://doi.org/10.1007/978-3-319-23075-7.

185. Ryu C-M, Hu C-H, Locy RD, Kloepper JW. Study of mechanisms for plant growth promotion elicited by rhizobacteria in Arabidopsis thaliana. Plant Soil. 2005;268(1):285-92.

186. Santos I, Bettiol W. Effect of sewage sludge on the rot and seedling damping-off of bean plants caused by Sclerotium rolfsii. Crop Prot. 2003;22:1093-7.

187. Santos JA, Nuñes LAPL, Melo WJ, Araujo ASF. Tannery sludge compost amendment rates on soil microbial biomass of two different soils. Eur J Soil Biol. 2011;47:146-51.

188. Scheuerell SJ, Sullivan DM, Mahaffee WF. Suppression of seedling damping-off caused by Pythium ultimum, P irregulare and Rhizoctonia solani in container media amended with a diverse range of Pacific Northwest compost sources. Phytopathology. 2005;95:306-15.

189. Schoch CL, Seifert KA, Huhndorf S, Robert V, Spouge JL, Levesque CA, Chen W. Nuclear ribosomal internal transcribed spacer (ITS) region as a universal DNA barcode marker for Fungi. Proc Natl Acad Sci USA. 2012;109(16):6241-6. 
190. Scotti R, Pane C, Spaccini R, Palese AM, Piccolo A, Celano G, Zaccardelli M. On-farm compost: a useful tool to improve soil quality under intensive farming systems. Appl Soil Ecol. 2016;107:13-23.

191. Sekse C, Holst-Jensen A, Dobrindt U, Johannessen GS, Li W, Spilsberg B, Shi J. High throughput sequencing for detection of foodborne pathogens. Front. Microbiol. 2017;8:2029. https://doi.org/10.3389/ fmicb.2017.02029.

192. Shekhar N, Bhattacharya D, Kumar D, Gupta RK. Biocontrol of woodrotting fungi with Streptomyces violaceus-Niger XL-2. Can J Microbiol. 2006;52:805-8.

193. Shen Z, Xue C, Penton CR, Thomashow LS, Zhang N, Wang B, Ruan Y, Li R, Shen Q. Suppression of banana Panama disease induced by soil microbiome reconstruction through an integrated agricultural strategy. Soil Biol Biochem. 2019;128:164-74. https://doi.org/10.1016/J. SOILBIO.2018.10.016.

194. Shen Z, Xue C, Taylor PWJ, Ou Y, Wang B, Zhao Y, Ruan Y, Li R, Shen Q Soil pre-fumigation could effectively improve the disease suppressiveness of biofertilizer to banana Fusarium wilt disease by reshaping the soil microbiome. Biol Fert Soils. 2018;54:793-806. https://doi. org/10.1007/s00374-018-1303-8.

195. Shi L, Du N, Shu S, Sun J, Li S, Guo S. Paenibacillus polymyxa NSY50 suppresses Fusarium wilt in cucumbers by regulating the rhizospheric microbial community. Sci Rep. 2017;7:412-34.

196. Siddiqui Y, Naidu Y, Ali A (2015) Bio-intensive management of fungal diseases of fruits and vegetables utilizating compost and compost teas. In: Meghvansi MK, Varma A (Eds.) Organic amendments and soil suppressiveness in plant disease management 2015, pp. 307-330. Springer Series Soil biology, Vol. 46, ISSN 1613-3382, ISSN 21964831 (electronic), ISBN 978-3-319-23074-0, ISBN 978-3-319-23075-7 (eBook). Springer International Publishing Switzerland. http://doi. org/10.1007/978-3-319-23075-7.

197. Singer E, Bushnell B, Coleman-Derr D, Bowman B, Bowers RM, Levy A, et al. High-resolution phylogenetic microbial community profiling. ISME J. 2016;10:2020-32. https://doi.org/10.1038/ismej.2015.249.

198. Slatko BE, Garner AF, Ausubel FM. Overview of next-generation sequencing technologies. Curr Protoc Mol Biol. 2018;122:e59. https:// doi.org/10.1002/cpmb.59.

199. Sommermann L, Geistlinger J, Wibberg D, Deubel A, Zwanzig J, Babin D, et al. Fungal community profiles in agricultural soils of a long-term field trial under different tillage, fertilization and crop rotation conditions analyzed by high-throughput ITS-amplicon sequencing. PLoS ONE. 2018:13(4):e0195345. https://doi.org/10.1371/journal.pone.0195345.

200. Suàrez-Estrella F, Vargas-Garcì C, Lopez MJ, Capel C, Moreno J. Antagonistic activity of bacteria and fungi from horticultural compost against Fusarium oxysporum f sp melonis. Crop Prot. 2007;26:46-53.

201. Sundquist A, Bigdeli S, Jalili R, Druzin ML, Waller S, Pullen KM, et al. Bacterial flora-typing with targeted, chip-based Pyrosequencing. BMC Microbiol. 2007;7(1):108

202. Tejada M, Hernandez MT, Garcia C. Soil restoration using composted plant residues: effects on soil properties. Soil Tillage Res. 2009:102:109-17.

203. Termorshuizen AJ, Jeger MJ. Strategies of soil-borne plant pathogenic fungi in relation to disease suppression. Fungal Ecol. 2008;1:108-14.

204. Termorshuizen AJ, van Rijn E, van der Gaag DJ, Alabouvette C, Chen Y, Lagerlof J, Malandrakis AA, Paplomatas EJ, Ramert B, Ryckeboer J, Steinberg C, Zmora-Nahum S. Suppressiveness of 18 composts against 7 pathosystems: variability in pathogen response. Soil Biol Biochem. 2006:38:2461-77.

205. Tiemann LK, Grandy AS, Atkinson EE, Marin-Spiotta E, McDaniel MD. Crop rotational diversity enhances belowground communities and functions in an agroecosystem. Ecol Lett. 2015;18:761-71.

206. Timmusk S, Nicander B, Granhall U, Tillberg E. Cytokinin production by Paenibacillus polymyxa. Soil Biol Biochem. 1999;31(13):1847-52.

207. Tiquia SM. Microbial community dynamics in manure composts based on $16 \mathrm{~S}$ and $18 \mathrm{~S}$ rDNA T-RFLP profiles. Environ Technol. 2005;26(10):1101-13.

208. Toju H, Peay KG, Yamamichi M, Narisawa K, Hiruma K, Naito K, Fukuda S, Ushio M, Nakaoka S, Onoda Y, Yoshida K, et al. Core microbiomes for sustainable agroecosystems. Nat Plants. 2018;4:247-57. https://doi. org/10.1038/s41477-018-0139-4.
209. Torres IF, Bastida F, Hernández T, García C. The effects of fresh and stabilized pruning wastes on the biomass, structure and activity of the soil microbial community in a semiarid climate. Appl Soil Ecol. 2015;89:1-9.

210. Trillas MI, Casanova E, Cotxarrera L, Ordovàs J, Borrero C, Avilés M. Composts from agricultural waste and the Trichoderma asperellum strain T-34 suppress Rhizoctonia solani in cucumber seedlings. Biol Control. 2006:39:32-8

211. Tyson GW, Chapman J, Hugenholtz P, Allen EE, Ram RJ, Richardson PM, Solovyev VV, Rubin EM, Rokhsar DS, Banfield JF. Community structure and metabolism through reconstruction of microbial genomes from the environment. Nature. 2004;428(6978):37-43. https://doi. org/10.1038/nature02340.

212. Val-Moraes SP. 2015. Suppressiveness in different soils for Rhizoctonia solani. In: Meghvansi MK, Varma A (Eds.) Organic amendments and soil suppressiveness in plant disease management 2015, pp. 175-186. Springer Series Soil biology, Vol. 46, ISSN 1613-3382, ISSN 21964831 (electronic), ISBN 978-3-319-23074-0, ISBN 978-3-319-23075-7 (eBook). Springer International Publishing Switzerland. http://doi. org/10.1007/978-3-319-23075-7.

213. Venter JC, Remington $\mathrm{K}$, Heidelberg JF, Halpern AL, Rusch D, Eisen JA, Wu D, Paulsen I, Nelson KE, Nelson W, Fouts DE, Levy S, Knap AH, Lomas MW, Nealson K, White O, Peterson J, Hoffman J, Parsons R, Baden-Tillson H, Pfannkoch C, Rogers YH, Smith HO. Environmental genome shotgun sequencing of the Sargasso Sea. Science. 2004;304(5667):66-74. https ://doi.org/10.1126/science.1093857.

214. Vinale F, Flematti G, Sivasithamparam K, Lorito M, Marra R, Skelton BW, Ghisalberti EL. Harzianic acid, an antifungal and plant growth promoting metabolite from Trichoderma harzianum. J Natl Prod. 2009;72(11):2032-5.

215. Vitullo D, Altieri R, Esposito A, Nigro F, Ferrara M, Alfano G, Ranalli G, De Cicco V, Lima G. Suppressive biomasses and antagonist bacteria for an eco-compatible control of Verticillium dahliae on nursery-grown olive plants. Int J Environ Sci Technol. 2013;10:209-20.

216. von der Weid I, Duarte GF, van Elsas JD, Seldin L. Paenibacillus brasilensis sp. nov., a novel nitrogen-fixing species isolated from the maize rhizosphere in Brazil. Int J Syst Evol Microbiol. 2002;52(6):2147-53.

217. Wan TT, Zhao HH, Wang W. Effect of biocontrol agent Bacillus amyloliquefaciens SN16-1 and plant pathogen Fusarium oxysporum on tomato rhizosphere bacterial community composition. Biol Control. 2017;112:1-9.

218. Wang B, Li R, Ruan Y, Ou Y, Zhao Y, Shen Q. Pineapple-banana rotation reduced the amount of Fusarium oxysporum more than maize-banana rotation mainly through modulating fungal communities. Soil Biol Biochem. 2015;86:77-86.

219. Wang $S$, Liang Y, Shen T, Yang H, Shen B. Biological characteristics of Streptomyces albospinus CT205 and its biocontrol potential against cucumber Fusarium wilt. Biocontrol Sci. Technol. 2016;26(7):951-63.

220. Wang Y, Qian PY. Conservative fragments in bacterial 165 rRNA genes and primer design for $16 \mathrm{~S}$ ribosomal DNA amplicons in metagenomic studies. PLoS ONE. 2009;4:10.

221. Wang B, Yuan J, Zhang J, Shen Z, Zhang M, Li R, Ruan Y, Shen Q. Effects of novel bioorganic fertilizer produced by Bacillus amyloliquefaciens W19 on antagonism of Fusarium wilt of banana. Biol Fertil Soils. 2013;49:435-46.

222. Wei G, Kloepper JW, Tuzun S. Induction of systemic resistance of cucumber to Colletotrichum orbiculare by select strains of plant growthpromoting rhizobacteria. Phytopathology. 1991;81(11):1508-12.

223. Wei Z, Yang X, Yin S, Shen Q, Ran W, Xu Y. Efficacy of Bacillus-fortified organic fertiliser in controlling bacterial wilt of tomato in the field. Appl Soil Ecol. 2011:48:152-9.

224. Weller DM, Raaijmakers JM, Gardener BM, Thomashow LS. Microbial populations responsible for specific soil suppressiveness to plant pathogens. Annu Rev Phytopathol. 2002;40:309-48.

225. White TJ, Bruns TD, Lee S, Taylor J. Amplification and direct sequencing of fungal ribosomal RNA genes for phylogenetics. In: Innis MA, Gelfauld DH, Sninsky JJ, White TJ, editors. PCR protocols: a guide to methods and applications. San Diego (USA): Academic Press; 1990. p. 315-22.

226. Wu B, Wang X, Yang L, Yang H, Zeng H, Qiu Y, Wang C, Yu J, Li J, Xu D, He Z, Chen S. Effects of Bacillus amyloliquefaciens ZM9 on bacterial wilt and rhizosphere microbial communities of tobacco. Appl Soil Ecol. 2016:103:1-12. 
227. Wu HS, Yang XN, Fan JQ, Miao WG, Ling N, Xu YC, Huang QW, Shen Q. Suppression of Fusarium wilt of watermelon by a bio-organic fertilizer containing combinations of antagonistic microorganisms. Biocontrol. 2009;54:287-300.

228. Xiong W, Li R, Ren Y, Liu C, Zhao Q, Wu H, Jousset A, Shen Q. Distinct roles for soil fungal and bacterial communities associated with the suppression of vanilla Fusarium wilt disease. Soil Biol Biochem. 2017;107:198-207.

229. Xu LH, Ravnskov S, Larsen J, Nilsson RH, Nicolaisen M. Soil fungal community structure along a soil health gradient in pea fields examined using deep amplicon sequencing. Soil Biol Biochem. 2012;46:26-32.

230. Xuan DT, Guong VT, Rosling A, Alstrom S, Chai BL, Hogberg N. Different crop rotation systems as drivers of change in soil bacterial community structure and yield of rice, Oryza sativa. Biol Fertil Soils. 2012;48:217-25.

231. Yamada KD, Tomii K, Katoh K. Application of the MAFFT sequence alignment program to large data-reexamination of the usefulness of chained guide trees. Bioinformatics. 2016;32:3246-51.

232. Yadav RS, Panwar J, Meena HN, Thirumalaisamy PP, Meena RL. Developing disease-suppressive soil through agronomic management. In: Meghvansi MK, Varma A (Eds.) Organic amendments and soil suppressiveness in plant disease management 2015, pp. 61-94. Springer Series Soil biology, Vol. 46, ISSN 1613-3382, ISSN 2196-4831 (electronic), ISBN 978-3-319-23074-0, ISBN 978-3-319-23075-7 (eBook). Springer International Publishing Switzerland. http://doi.org/10.1007/978-3-319-23075 -7 .

233. Yang $X$, Chen $L$, Yong $X$, Shen $Q$. Formulations can affect rhizosphere colonization and biocontrol efficiency of Trichoderma harzianum SQR-T037 against Fusarium wilt of cucumbers. Biol Fertil Soils. 2011:47:239-48.

234. Yang W, Jing X, Guan Y, Zhai C, Wang T, Shi D, Sun W, Gu S. Response of fungal communities and co-occurrence network patterns to compost amendment in black soil of Northeast China. Front Microbiol. 2019;10:1562. https://doi.org/10.3389/fmicb.2019.01562.
235. Yang X, Noyes NR, Doster E, Martin JN, Linke LM, Magnuson RJ, Yang H, Geornaras I, Woerner DR, Jones KL, Ruiz J, Boucher C, Morley PS, Belk KE. Use of metagenomic shotgun sequencing technology to detect foodborne pathogens within the microbiome of the beef production chain. Appl Environ Microbiol. 2016;82:2433-43. https://doi.org/10.1128/ AEM.00078-16.

236. Yin C, Jones KL, Peterson DE, Garrett KA, Hulbert SH, Paulitz TC. Members of soil bacterial communities sensitive to tillage and crop rotation. Soil Biol Biochem. 2010;42:2111-8.

237. Zaccardelli M, de Nicola F, Villecco D, Scotti R. The development and suppressive activity of soil microbial communities under compost amendment. J Soil Sci Plant Nutr. 2013;13:730-42.

238. Zhang M, Li R, Cao L, Shi J, Liu H, Huang Y, Shen Q. Algal sludge from Taihu Lake can be utilized to create novel PGPR-containing bioorganic fertilizers. J Environ Management. 2014;132:230-6. https://doi. org/10.1016/J.JENVMAN.2013.10.031.

239. Zhao Q, Dong C, Yang X, Mei X, Ran W, Shen Q, Xu Y. Biocontrol of Fusarium wilt disease for Cucumis melo melon using bio-organic fertilizer. Appl Soil Ecol. 2011;47:67-75.

240. Zhao N, Li R, Xin K, Zhao Y, Ruan Y, Fu C. Effects of different solanaceae crop rotations on the soil culturable microbes in an orchard with serious fusarium wilt disease. Chin J Tropical Crops. 2014;35:1469-74.

241. Zhao Q, Xiong W, Xing Y, Sun Y, Lin X, Dong Y. Long-term coffee monoculture alters soil chemical properties and microbial communities. Sci Rep. 2018;8:6116. https://doi.org/10.1038/s41598-018-24537-2.

242. Zhen Z, Liu HT, Wang N, Guo LY, Meng J, Ding N, Wu GL, Jiang GM. Effects of manure compost application on soil microbial community diversity and soil microenvironments in a temperate cropland in China. PLoS ONE. 2014;9:e108555.

\section{Publisher's Note}

Springer Nature remains neutral with regard to jurisdictional claims in published maps and institutional affiliations.

\section{Submit your manuscript to a SpringerOpen ${ }^{\circ}$ journal and benefit from:}

- Convenient online submission

- Rigorous peer review

- Open access: articles freely available online

- High visibility within the field

- Retaining the copyright to your article

Submit your next manuscript at $\boldsymbol{\nabla}$ springeropen.com 